\title{
BRASILEÑOS ASILADOS EN MÉXICO. DOS CASOS DE EXCEPCIÓN
}

\author{
Daniela Morales Muñoz \\ El Colegio de México ${ }^{1}$
}

$\mathrm{D}$ urante la segunda mitad del siglo xx se registró en América Latina un proceso de masificación de las migraciones políticas como consecuencia de la imposición en varios países de la región de regímenes totalitarios que, apoyados en el contexto de polarización política de la guerra fría y de doctrinas y leyes de seguridad nacional, intensificaron el uso del exilio político como medida represiva y de exclusión forzada. ${ }^{2}$

Ante los graves escenarios de violencia estatal, instaurados especialmente en las décadas de 1960 y 1970 en los países del Cono Sur, miles de militantes del movimiento social ${ }^{3}$ fueron obligados

Fecha de recepción: 20 de mayo de 2019

Fecha de aceptación: 7 de noviembre de 2019

${ }^{1}$ Este artículo se realizó con el apoyo de una beca posdoctoral del Conacyt.

${ }^{2}$ Mario Sznajder y Luis Roniger han explicado cómo ese proceso de masificación del exilio se dio de manera paralela a la transformación de la naturaleza de los conflictos sociales y políticos en la región. SNAJDER y RONIGER, La política del destierro y el exilo en América Latina, pp. 172-235.

${ }^{3}$ En ese término incluimos a funcionarios de los gobiernos derrocados, militantes de partidos políticos de izquierda, del movimiento sindical, obrero, cultural, estudiantil y de organizaciones armadas. 
a salir al exilio como única alternativa para resguardar la vida, la libertad y la integridad física. En cada coyuntura recurrieron a formas particulares de salida, encontrando diferentes respuestas en los países donde buscaron protección.

La historiografía del exilio latinoamericano ha mostrado que México, acorde con una tradición de país "de puertas abiertas" a los perseguidos políticos, desempeñó un papel central en la protección de grandes contingentes de exiliados sudamericanos particularmente en la década de 1970, cuando abrió sus puertas a miles de exiliados argentinos, chilenos y uruguayos, perseguidos por las dictaduras militares instauradas en sus países entre 1973 y $1976 .^{4}$

Esas experiencias de exilio conosureño en México, que fueron las más numerosas, han sido conocidas mediante una importante producción de trabajos de carácter testimonial ${ }^{5}$ y de investigaciones que han abordado el estudio de cada comunidad de exiliados desde diferentes perspectivas, preguntando por ejemplo por sus dimensiones cuantitativas, ${ }^{6}$ sus características sociopolíticas, las políticas de recepción ${ }^{7}$ o las experiencias organizativas. ${ }^{8}$

En años recientes, el campo de estudio sobre los exilios latinoamericanos que llegaron a México durante la segunda mitad del siglo xx ha ido explorando otras experiencias de exilio que, quizá por haber sido menos numerosas en relación con los contingentes recibidos en la década de 1970, habían sido objeto

\footnotetext{
${ }^{4}$ Yankelevich, "Exilios: México en la memoria latinoamericana".

5 Yankelevich, En México entre exilios; Bernetti y Giardinelli, México, el exilio que hemos vivido. Memoria del exilio argentino en México durante la dictadura: 1976-1983; MEYER y SALGADO, Un refugio en la memoria; BURIAno, Dutrénit y Rodríguez de ITA, Tras la memoria. El asilo diplomático en tiempos de la Operación Cóndor.

${ }^{6}$ Yankelevich, Ráfagas de un exilio.

7 Díaz Prieto, "Un exilio venturoso: chilenos en México (1973-1990)".

8 Yankelevich, "La Comisión Argentina de Solidaridad"; Rojas Mira, "El exilio político chileno".
} 
de menor atención, como el caso de los exilios dominicano, ${ }^{9}$ salvadoreño, ${ }^{10}$ nicaragüense, ${ }^{11}$ boliviano ${ }^{12}$ o brasileño. ${ }^{13}$

Estas experiencias han permitido vislumbrar otras prácticas en materia de aplicación del asilo político y de las políticas de recepción de exiliados por parte del gobierno mexicano durante la segunda mitad del siglo xx que ayudan a complejizar la visión de México como país protector de perseguidos políticos.

El caso de los brasileños que llegaron a México entre 1964 y 1979, perseguidos por la dictadura militar que se instauró en ese país mediante un golpe de Estado civil-militar en abril de 1964, ha mostrado, por ejemplo, cómo en cada coyuntura de llegada los exiliados recibieron respuestas diferentes en relación con sus posibilidades de estancia en el país en función del contexto de salida; de las vías de ingreso al país; de los perfiles políticos de los exiliados y de la voluntad, las posturas ideológicas y las percepciones sobre lo que sucedía en Brasil de quien estaba al frente del gobierno de México; de sus representantes ante ese país y de sus autoridades migratorias. ${ }^{14}$

La historiografía existente sobre el exilio brasileño durante la última dictadura militar (1964-1985) poco se había ocupado del estudio de las experiencias de los expatriados brasileños en países en los que no se registró una presencia masiva de los mismos,

\footnotetext{
9 Véase Rodríguez de ItA, “Tres asilos otorgados por México a un mismo antitrujillista".

10 Pirker y NúÑez Rodríguez, "La revolución salvadoreña necesita de la solidaridad del pueblo mexicano".

11 Toussaint, “¿Activismo o intervencionismo?”.

12 Andújar De Jesús, "Exiliados bolivianos en la unam".

13 Morales Muñoz, El exilio brasileño en México; Salles, "Migrantes y trashumantes"; Hidalgo Castellanos, "Um olhar na vida de exilio de Francisco Julião"; Villanueva Velasco, "Brasil. Ámelo o déjelo"; De Andrade, "A trajetória de Francisco Julião no exiíio e as relações entre Brasil e México, 1965-1969”.

14 Morales Muñoz, El exilio brasileño en México.
} 
como fue el caso de México. La mayoría de las investigaciones, aunque no han sido demasiadas, se había concentrado hasta hace poco en el estudio de las experiencias de este exilio en los países que en determinadas coyunturas se convirtieron en polos de concentración de los brasileños, como fue el caso de Uruguay, entre 1964 y 1970; Chile, entre 1970 y 1973, y Francia, entre 1973 y $1979 .{ }^{15}$

En la última década han surgido trabajos desde diferentes perspectivas sobre experiencias de los brasileños en el exilio en países que no tuvieron presencia masiva de exiliados políticos, pero que por diferentes razones y en determinadas coyunturas se convirtieron en lugares importantes o incluso estratégicos para los expatriados brasileños. ${ }^{16}$

Ése fue el caso de México, que a pesar de nunca haber sido un polo de concentración para los brasileños perseguidos por el régimen militar, ${ }^{17}$ sí registró un ingreso constante de los mismos a lo largo de los quince años que transcurrieron entre el golpe de estado en 1964 y la promulgación de la Ley de Amnistía que

${ }^{15}$ El estudio pionero del exilio brasileño, Exilio: entre raízes e radares, de Denise Rollemberg, relaciona estos polos de concentración con el exilio de dos generaciones distintas. Mientras que en Uruguay se concentró la mayor parte de la generación de 1964, que salió de Brasil entre 1964 y 1966 como consecuencia inmediata del derrocamiento del gobierno de João Goulart, Chile y después Francia se identifican como los principales centros de reunión de perseguidos políticos brasileños de la generación de 1968, expulsada de su país tras el inicio del periodo más represivo de la dictadura militar.

Entre los trabajos que han estudiado estos lugares de exilio se encuentran Da Cruz, "Frente Brasileño de Informaciones e Campanha"; SCHNEIder Marques, "Ditadura, exílio e oposição"; Schneider Marques, "Marcha e os exiliados brasileiros no Uruguay"; SChneIder Marques, "O exílio e as transformações de ação coletiva”.

16 Prestes Massena, "Entre Brasil e Moçambique"; Da Cruz, "Brasileiros no exílio"; Villanueva Velasco, "Brasil. Ámelo o déjelo"; Sáenz Carrete, "El exilio brasileño en Chile, Francia y México".

17 Se calcula que entre 1964 y 1979 salieron alrededor de 10000 brasileños al exilio. Pereira, Ditadura e repressão, p. 56. 
marcó el fin del exilio, en 1979. Durante ese periodo, para un pequeño grupo de brasileños -alrededor de 30-, México fue importante como lugar de exilio en la medida en que les permitió reunir a sus familias, reconstruir sus vidas, mantener cierto grado de militancia política, trabajar y estudiar. Sin embargo, para la mayoría de los casi doscientos brasileños que durante los años del exilio pasaron por este país, México fue fundamentalmente un punto de tránsito hacia otros lugares. ${ }^{18}$

De acuerdo con la periodización propuesta por la socióloga Vania Salles, con la que concuerdan muchos otros brasileños que estuvieron exiliados en México, los perseguidos por el régimen militar brasileño ingresaron a este país fundamentalmente en tres coyunturas. La primera y más grande oleada llegaría entre 1964 y 1966 vía el asilo diplomático que se concedió a casi un centenar de personas que tuvieron que salir de Brasil como consecuencia inmediata del golpe de estado y el inicio de la persecución política que tenía por objetivo desmantelar a la élite política e intelectual asociada con el gobierno de João Goulart y sus lazos organizativos con los movimientos sociales de base popular. $^{19}$

El segundo momento de ingreso de exiliados brasileños a México se identifica a partir de 1969, tras la promulgación en Brasil del Acta Institucional número 5 (AI-5), en diciembre de 1968, que marca el inicio del periodo más represivo de la dictadura brasileña, asociado con el desmantelamiento de las organizaciones revolucionarias que se habían fortalecido con la fuerte represión al movimiento estudiantil y la cancelación de toda posibilidad de participación política de los jóvenes estudiantes y de otros sectores de oposición al régimen.

${ }_{18}$ Morales Muñoz, El exilio brasileño en México.

19 En esta coyuntura, el entonces embajador de México en Brasil, Alfonso García Robles, con la anuencia del presidente Adolfo López Mateos, otorgó asilo político a la totalidad de personas que lo solicitaron. 
Una tercera oleada de ingreso a México se identifica en 1973, con la llegada de brasileños procedentes de Chile que huían de la represión desatada en ese país tras el golpe de estado que derrocó al gobierno de Salvador Allende.

Gran parte de los brasileños que se asilaron en México entre 1964 y 1979 lo hicieron por la vía del asilo diplomático que obtuvieron en su país por medio de la embajada mexicana en Río de Janeiro; sin embargo, al finalizar la década de 1960 identificamos dos casos de asilo político que consideramos excepcionales, tanto por la forma en la que se presentaron ante el gobierno mexicano, como por el trato que éste les dio a los mismos.

En el primer caso, el gobierno de Gustavo Díaz Ordaz concedió asilo político a una veintena de presos políticos brasileños en el marco de dos situaciones críticas: el secuestro, en septiembre de 1969 y marzo de 1970, de dos funcionarios diplomáticos por parte de organizaciones armadas brasileñas que a cambio de liberarlos exigieron al gobierno militar la excarcelación y el envío inmediato al exilio de 15 presos políticos en la primera operación y 5 en la segunda. Como se ahondará más adelante, lo excepcional en estos episodios radicó en la concesión del asilo político a un grupo de personas vinculadas o beneficiadas con una acción de la guerrilla en Brasil; en la celeridad con la que el gobierno mexicano concedió el asilo, y en la imposición en México de un fuerte esquema de vigilancia a los asilados.

El segundo caso se dio en 1973, cuando en el contexto del golpe militar que derrocó al gobierno de Salvador Allende en Chile el gobierno de México protegió en su embajada de Santiago a un grupo de 43 brasileños que fueron perseguidos por la junta militar chilena. Como se verá, lo excepcional en este caso no sólo fue brindar protección a personas que habían sido desterradas de su país y perseguidas en su país de asilo sino, sobre todo, el trato diferente que recibieron en México respecto del que el gobierno de Luis Echeverría ofreció en la misma coyuntura a los exiliados de origen chileno. 
La mayoría de los brasileños que fueron asilados en estas dos situaciones de excepción habían sido desterrados por decreto, pues al haber salido al exilio por la vía de acciones revolucionarias impuestas al régimen militar fueron castigados con la pena del banimento, ${ }^{20}$ una medida jurídica que, además de implicar la pérdida de su nacionalidad y la prohibición de volver a ingresar a su país, se pensó como un estigma que pudiera distinguirlos y afectarles negativamente en el exilio.

Se trata de experiencias de asilo político que no tenían precedente en México y por lo tanto resultan ilustrativas de otro tipo de comportamientos que tuvo el gobierno mexicano frente a las migraciones políticas latinoamericanas durante la segunda mitad del siglo xx.

En este artículo nos proponemos documentar estos casos excepcionales en materia de asilo político en México; analizar las condiciones en las que los gobiernos de Gustavo Díaz Ordaz y Luis Echeverría Álvarez otorgaron la prerrogativa a estos grupos de brasileños desterrados; explorar las particularidades y los límites de la protección que les brindaron en este país, y delinear algunas hipótesis que puedan explicar el comportamiento del gobierno mexicano frente a los casos mencionados.

\section{ASILO POLÍTICO A PRISIONEROS LIBERADOS}

A las 12:45 del domingo 7 de septiembre de 1969 aterrizó en el aeropuerto internacional de la Ciudad de México el avión C-130 de la Fuerza Aérea Brasileña Hércules 56. Traía a bordo a 15 presos políticos -14 hombres y una mujer- de la dictadura militar brasileña que habían sido liberados y enviados al exilio por exigencia de las organizaciones guerrilleras Ação Libertadora Nacional (ALN) y Movimento Revolucionário 8 de Outubro

\footnotetext{
${ }^{20}$ El banimento se puede traducir o entender como un destierro asignado por decreto.
} 
(MR-8), cuyos militantes habían capturado dos días atrás al embajador de Estados Unidos, Charles Burke Elbrick, como medida de presión al régimen.

Además de la liberación de los presos políticos y su envío inmediato al exilio, las organizaciones exigieron como condición para la liberación del diplomático, la divulgación íntegra, en los principales periódicos, radios y televisiones de Brasil, de un manifiesto revolucionario que denunciaba la opresión, explotación y represión del régimen ${ }^{21}$ que se había impuesto en marzo de 1964 por la vía de un golpe de estado civil-militar en contra del presidente João Goulart.

Establecieron un plazo de 48 horas a la junta militar que se había renovado apenas cuatro días atrás, ${ }^{22}$ para responder a sus exigencias, y una vez aceptadas las condiciones, dieron un día más para que los 15 presos políticos fueran trasladados en un avión especial hasta Argelia, Chile o México, cualquiera de estos tres países donde se les concediera asilo político.

El secuestro del embajador estadounidense era la más osada y espectacular acción revolucionaria que se había registrado en Brasil desde que los militares habían tomado el poder en 1964, y evidentemente, significó un gran golpe político de alcance internacional para el régimen, pues la operación se divulgó rápidamente por todo el mundo con la denuncia implícita de la existencia de presos políticos en Brasil y de los terribles niveles de represión que se habían alcanzado en ese país, particularmente a raíz de la promulgación, el 13 de diciembre de 1968, del Acta Institucional número 5 (AI-5), un decreto que los militares

21 "Manifiesto de ALN y MR-8 ante el secuestro del embajador de los EE.UU. Charles Burke Elbrick” 1 de septiembre de 1969, Brasil. Recuperado de http:// www.cedema.org/ver.php?id=327 Consultado el 14 de enero de 2019.

22 Durante los meses de agonía del presidente Artur da Costa e Silva se impuso en el gobierno un "triunvirato" o Segunda Junta Militar, integrado por los ministros de las tres armas: Ejército, Aeronáutica y Marina, que estuvo en funciones entre el 31 de agosto y el 30 de octubre de 1969. 
impusieron como respuesta a la creciente movilización social -especialmente en el sector estudiantil- que se había registrado en el año de 1968 y que inauguró el periodo más represivo de la dictadura militar.

Entre el 4 y el 7 de septiembre de 1969, días que corrieron entre la captura del diplomático y el envío al exilio de los presos políticos, se vivieron momentos de enorme tensión política en Brasil a donde inevitablemente se habían volcado los reflectores del mundo. La junta militar debía actuar con enorme premura, no sólo para cumplir los plazos impuestos por las organizaciones revolucionarias, identificadas en la prensa local e internacional como "terroristas", sino también para evitar que un sector del Ejército, que se oponía rotundamente a aceptar las condiciones de los guerrilleros, obstruyera la operación de rescate del embajador estadounidense al impedir, como se había propuesto a toda costa, la salida de los prisioneros al exterior.

El gobierno de Estados Unidos presionó a la junta militar brasileña para evitar que se impusiera esa tendencia del Ejército que se oponía a negociar y solicitó cuanto antes la cooperación del gobierno mexicano para que otorgara asilo político a los 15 prisioneros que serían liberados a cambio del embajador estadounidense, lo que el gobierno de Gustavo Díaz Ordaz autorizó de manera inmediata. ${ }^{23}$

El gobierno de Chile había anunciado previamente su disposición de asilar a los 15 prisioneros políticos, pero el gobierno de Brasil se opuso debido a la proximidad geográfica de ese país. ${ }^{24}$ Para el gobierno de Díaz Ordaz se trataba de una situación excepcional. No había antecedentes del otorgamiento de asilo político en una situación semejante. Precisamente, en su sexto y último informe de gobierno el presidente marcó el contraste

${ }^{23}$ Departament of State, "Elbrick Chronology”, Washington, 4 de septiembre de 1970, National Archives, serie: Redords Relating to Brazil 1962-1975, File: Kidnapping of Ambassadors.

${ }^{24}$ Departament of State, "Elbrick Chronology", p. 4. 
entre los asilos políticos que "México continúa otorgando en sus embajadas a quienes lo solicitan y han demostrado, a juicio de nuestros agentes diplomáticos, tener derecho a la protección de esa noble institución latinoamericana", y los casos que "con nuevas características se han presentado últimamente", refiriéndose a los asilos otorgados a solicitud de los gobiernos que estaban siendo forzados a liberar presos políticos y enviarlos al exilio mediante acciones revolucionarias.

En el caso de los asilos que se otorgan por medio de las embajadas, señaló, México responde en consecuencia con "la generosa y muy vieja tradición que tiene el derecho de asilo entre nosotros". En el segundo caso, "hemos actuado con sentido humanitario y espíritu de colaboración para los gobiernos dentro de cuya jurisdicción se realizan los actos que dan motivo a la solicitud y siempre a petición expresa de esos gobiernos". ${ }^{25}$

Efectivamente, durante el sexenio de Díaz Ordaz, la embajada de México en Brasil otorgó asilo político a 27 personas que lo solicitaron. No obstante, la política que en esa materia se aplicó por medio de su embajador en Río de Janeiro, Vicente Sánchez Gavito, se caracterizó por ser mucho más estricta en relación con la que se había aplicado en el contexto del golpe de estado durante los últimos meses de gobierno de Adolfo López Mateos. Se trataba de un endurecimiento discreto que pretendía, por un lado, cuidar el prestigio de México en materia de asilo, y, por otro, evitar que la recepción de asilados se convirtiera en motivo de conflicto con el régimen militar. En palabras del propio embajador, la política a seguir en materia de asilo fue tratar cada caso de forma "cortés y amistosa" y "evitar que el asilo diplomático se convirtiera en causa de la más mínima irritación entre los dos gobiernos". Esa decisión derivó en algunas

25 Centro de documentación, información y análisis, Informes presidenciales. Gustavo Díaz Ordaz, p. 431. 
negativas de asilo, demoras, y en un importante cambio de actitud hacia los asilados. ${ }^{26}$

El 7 de septiembre, día de la independencia en Brasil, los 15 prisioneros políticos fueron reunidos y embarcados en el avión de la Fuerza Aérea Brasileña Hércules 56 y, atados de pies, manos y cintura; escoltados por 10 soldados y sin derecho a la palabra, emprendieron un tortuoso vuelo rumbo a México.

\section{Foto 1}

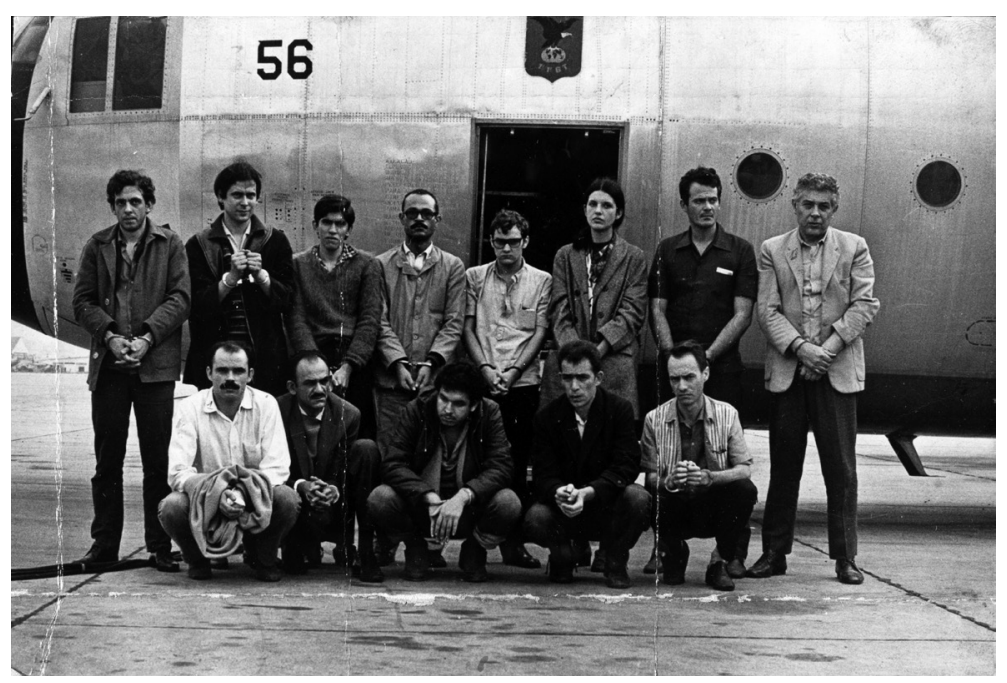

Trece de los 15 presos políticos reunidos en la Base Aérea do Galeão, Río de Janeiro, minutos antes de embarcar rumbo a México. De pie, a partir de la izquierda: Luis Travassos, José Dirceu, José Ibrahim, Onofre Pinto, Ricardo Vilas, Maria Augusta Carneiro, Ricardo Zarattini y Rolando Frati. En cuclillas: João Leonardo, Agonalto Pacheco, Vladimir Palmeira, Ivens Marchetti y Flávio Tavares. APESP, fondo Última Hora, referencia ICO_UH_033-042.

${ }^{26}$ Vicente Sánchez Gavito, "Memorandum”, Río de Janeiro, 2 de julio de 1969. AHI-MRE, exp. Notas recibidas por Itamaraty procedentes de la embajada de México (1969). Véase Morales Muñoz, El exilio brasileño en México, pp. 109-125. 
La lista de los presos políticos rescatados estaba integrada por militantes de prácticamente todas las tendencias de la izquierda brasileña, que para esos años ya tenía una gran presencia de las organizaciones armadas. La encabezaba el legendario militante del Partido Comunista Brasileiro Gregório Bezerra, el más antiguo preso político en Brasil que había sido detenido inmediatamente después del golpe de 1964. Figuraban también los principales dirigentes estudiantiles de 1968: Vladimir Palmeira, José Dirceu y Luís Travassos; los estudiantes y militantes de la Dissidência Comunista da Guanabara (DI-GB), Ricardo Vilas Boas y Maria Augusta Carneiro Ribeiro; el dirigente metalúrgico y militante de la Vanguarda Popular Revolucionária (VPR) que en 1968 había liderado la huelga de Osasco, José Ibrahim; el periodista y militante del Movimento Acción Revolucionária (MAR), Flávio Tavares; el exsargento y fundador de vPR, Onofre Pinto; los militantes de Aln, Agonalto Pacheco, Mário Zanconato, João Leonardo y Rolando Fratti; el militante del Partido Comunista Brasileiro Revolucionario (PCBR), Ricardo Zarattini, y el militante de la Dissidência de Niterói, Ivens Marchetti. ${ }^{27}$

Aunque sabían que su traslado era parte de la operación de rescate que habían realizado las organizaciones ALN y MR-8, durante gran parte del trayecto varios de ellos ignoraban cuál sería el destino de ese vuelo y por la mente de algunos incluso cruzó la idea de que serían arrojados al mar.

De acuerdo con los testimonios y las crónicas periodísticas, en el aeropuerto internacional de la ciudad de México los presos

27 DA-Rin, Hércules 56, p. 15. El libro es una recopilación de los testimonios que el propio Da-Rin recogió para el documental "Hércules 56" que dirigió en 2006 sobre la retención del embajador de Estados Unidos y la liberación y envío al exilio de los 15 presos políticos brasileños. Sobre el episodio del rapto del embajador Charles Burke Elbrick en Brasil también se realizó la película Cuatro dias de septiembre, dirigida en 1997 por Bruno Barreto, quien realizó una adaptación de la obra autobiográfica O que é isso, companheiro?” de Fernando Gabeira. 
brasileños fueron recibidos en medio de "un torbellino" en el que alrededor de 300 periodistas, funcionarios mexicanos, policías, guardias aduanales, diplomáticos estadounidenses y compatriotas radicados en México se disputaban a los recién llegados. ${ }^{28}$

La noticia de que habían llegado sanos y salvos era la señal para que el embajador Elbrick obtuviera su libertad, como efectivamente sucedió unas horas después en las inmediaciones del estadio Maracaná en Río de Janeiro.

El desembarque de los presos en México se complicó debido a que el comandante del avión, el mayor Egon Reinisch, se negaba a entregar a los prisioneros a las autoridades mexicanas alegando que para ello debía recibir indicaciones de manera personal de algún representante de la embajada de Brasil en México. Sin embargo, tras unos cuarenta minutos de confusión, el jefe de Migración del aeropuerto, Julio Cerecedo López, el subjefe de la oficina de Migración, Mario Valle, y el secretario particular del canciller mexicano, Carlos González Parrodi, se impusieron a los militares brasileños y les ordenaron no sólo la entrega inmediata de los prisioneros sino también su liberación, como lo recuerda el periodista Flávio Tavares, que formaba parte de aquel grupo de prisioneros:

El comandante del avión tenía la orden de entregarnos a la embajada brasileña, más o menos en la condición de prisioneros, y no al gobierno mexicano $[. .$.$] enseguida sube un señor así, bien mexicano,$ facciones indígenas, de anteojos, y nos mira y dice: ¡en México mandamos nosotros, quítenles las esposas y liberen a estos señores de inmediato! Y ahí, ese diplomático brasileño pregunta: pero, ¿quién es usted?, y él responde: soy Cerecedo López, jefe de Migración del

28 "Maniatados y hambrientos, llegaron los asilados brasileños", Excelsior (8 sep. 1969), p. 16-A. 


\section{Foto 2}

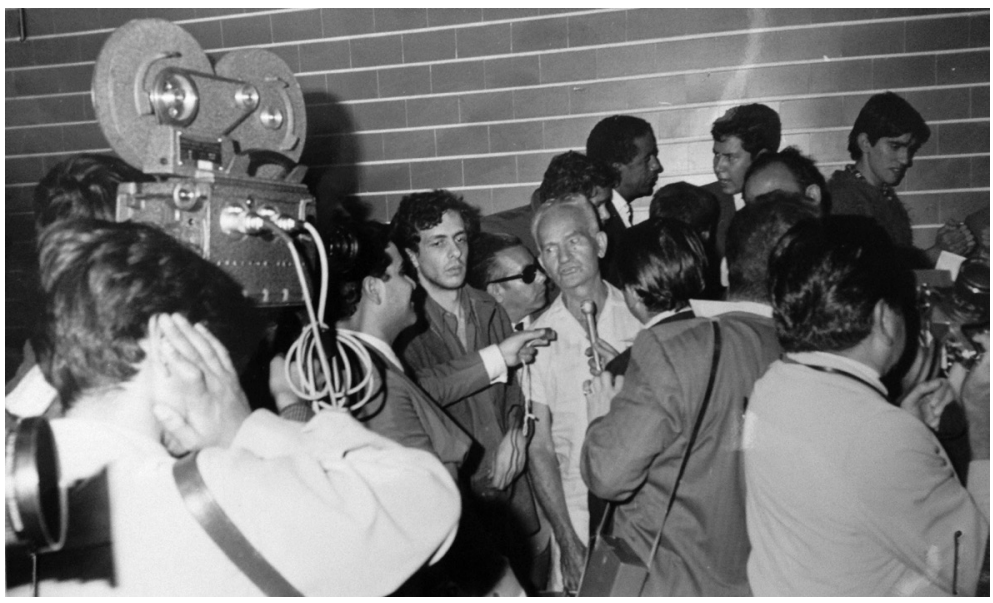

Los brasileños recién desembarcados en México son recibidos por una multitud de simpatizantes, connacionales, periodistas nacionales e internacionales, funcionarios mexicanos, policías y diplomáticos norteamericanos. En el centro de la imagen el histórico militante comunista Gregorio Bezerra, considerado el preso político más antiguo de la dictadura brasileña, habla con los reporteros. A su lado izquierdo lo acompaña el dirigente estudiantil Luis Travassos y a la derecha Agonalto Pacheco. Atrás de éste se distingue al líder sindical José Ibrahim. AGN, galería 1, DFS, exp.11-155-69.

L. 1.H. 61-69.

Aeropuerto Internacional de México. Ahí nos dimos cuenta de que ya dejábamos de ser presos, éramos inmigrantes [... ${ }^{29}$

Dos días atrás, el 5 de septiembre de 1969, el gobierno de Brasil había decretado el destierro de los 15 prisioneros mediante el Acta Institucional Número 13, que instituyó la pena del banimento del territorio nacional "para el brasileño que

29 Conversación con Flávio Tavares, Porto Alegre, Brasil, 30 de noviembre de 2013. 
se volviera inconveniente, nocivo o peligroso a la Seguridad Nacional". 30

En México, efectivamente, el gobierno de Díaz Ordaz los liberó y, tal como se había acordado desde antes de su traslado, les permitió internarse en el país bajo la calidad migratoria de asilados políticos. No obstante, de inmediato fueron concentrados en un hotel donde se les mantuvo bajo una estrecha vigilancia a cargo de la Dirección Federal de Seguridad (DFS), la policía política mexicana.

La vigilancia a los exiliados y asilados políticos por parte del gobierno mexicano no era una práctica nueva, sin embargo, con este grupo tuvo la particularidad de establecer una vigilancia abierta, pues dos policías plenamente identificados por ellos se apostaron afuera de sus habitaciones para vigilar y reportar cada uno de sus movimientos y sus contactos durante el día y la noche. Constantemente los agentes de seguridad les recomendaban no salir del hotel por razones de seguridad, pues la vigilancia se justificaba bajo el argumento de estarles brindando protección.

En el ámbito internacional se alarmaba con el incremento del "terrorismo internacional", categoría en la que, sin advertir los diferentes tipos de violencia política que existían en aquel contexto, inscribían a los grupos que en América Latina se habían planteado la vía armada para derrocar las dictaduras que, como la brasileña, se habían impuesto por medio de un golpe de Estado y se mantenían en el poder mediante una fuerte represión social. ${ }^{31}$

En la prensa mexicana este grupo de asilados brasileños fueron presentados, por un lado, como víctimas de un régimen militar represivo, y por otro, algunos de ellos fueron señalados como "elementos subversivos peligrosos" ${ }^{32}$ En las páginas de

30 Acta Institucional No. 13. Recuperado de https://legis.senado.leg.br/legislacao/DetalhaSigen.action?id=584065 Consultado el 14 de enero de 2019.

31 LARSOn, "La guerrilla en América Latina”, pp. 91-112.

32 "Vuela hacia México el avión con los 15 brasileños liberados", Excelsior (7 sep. 1969), p. 12. 
los periódicos mexicanos también se reprodujo la interpretación que sobre la acción guerrillera se hizo en la prensa brasileña, calificándola como una "acción terrorista" que formaba parte de una "conspiración internacional antinorteamericana", ejecutada por "una red de terrorismo continental de la que el terrorismo brasileño es sólo una rama". ${ }^{33}$

La vigilancia impuesta sobre los brasileños asilados en territorio mexicano muestra que el gobierno de Díaz Ordaz los consideró, en efecto, personas potencialmente peligrosas a las que tenía que tener bajo control. Consideración que coincide con la clasificación que hizo de ellos la dictadura militar al imponerles la pena del banimento.

Habían pasado once meses desde la matanza de estudiantes en la Plaza de las Tres Culturas en Tlatelolco y en el ambiente de la capital mexicana aún se respiraba la tragedia de aquella tarde, mientras que en el gobierno seguía viva la paranoia anticomunista de que una conspiración internacional pretendía "romper el orden constitucional".

La policía se quedó ahí en el hotel con nosotros con doble función: para protegernos y para vigilarnos. Nosotros llegamos el día 7 de septiembre del año 1969, once meses después de la matanza de Tlatelolco. Estaba todo muy al descubierto en México, en el DF más todavía. El drama, la tragedia de Tlatelolco estaba en los dos lados, en las víctimas y en la policía. La policía nos protegía y nos vigilaba. A nosotros no nos interesaba la vigilancia mexicana, nos interesaba la protección, teníamos mucho miedo de la CIA $[\ldots] .^{34}$

El temor no era infundado. Ese organismo estadounidense tenía una enorme injerencia en el gobierno de Gustavo Díaz

33 “México otorgó asilo político”, Excelsior (7 sep. 1969), p. 26-A.

34 Conversación con Flávio Tavares, Porto Alegre, Brasil, 30 de noviembre de 2013. 
Ordaz, ${ }^{35}$ durante el cual hubo una estrecha colaboración en el ámbito reservado de la seguridad con el gobierno de Estados Unidos en función de la convicción compartida de la necesidad de contener el avance del comunismo soviético en el contexto internacional de la guerra fría. ${ }^{36}$ Efectivamente, entre las actividades que se desempeñaban desde las oficinas de seguridad estadounidenses, incluida la estación local de la CIA, se encontraba la de vigilar y mantener bajo control a los revolucionarios latinoamericanos exiliados en México, ${ }^{37}$ lo que lograban, en buena medida, por medio de la DFS.

Evidentemente, los asilados brasileños liberados a cambio del diplomático estadounidense no tenían la certeza de que el órgano de seguridad de Estados Unidos tuviera tal injerencia en el gobierno de México, pero la proximidad geográfica de ambos países y el ambiente de control bajo el que los mantuvieron desde el primer momento en suelo mexicano les causaba gran inquietud.

Por otra parte, en Brasil hacía tiempo que circulaban denuncias en torno a la actuación del Serviço Nacional de Informações (SNI), el aparato de espionaje de la dictadura militar en el exterior. Años después, con la apertura de archivos en Brasil se fue documentando que la vigilancia de los exiliados durante la dictadura militar se realizó por medio del Centro de Informações do Exterior (CIEx) que, integrado al organigrama del Ministério de Relações Exteriores, fue creado con la misión de monitorear la actuación de éstos, especialmente de los banidos en relación, sobre todo, con su posible retorno a Brasil. ${ }^{38}$

35 Se ha documentado ya la existencia del programa LITEMPO, conformado por 14 agentes entre los que estaban el expresidente López Mateos, el propio Díaz Ordaz y su sucesor, Luis Echeverría Álvarez. Véase AguaYo, El 68. Los estudiantes, el presidente y la CIA.

36 Collado Herrera, "La Guerra Fría”, pp. 158-203.

37 Aguayo, La Charola, p. 160.

${ }^{38} \mathrm{La}$ actuación del aparato de represión brasileño en el exterior se fue documentando con la apertura de los archivos en ese país de las policías políticas estatales conocidas como Dops y el fondo de la Divisão de Segurança e 
Sin duda, el temor a los servicios de inteligencia brasileños y estadounidenses y la vigilancia impuesta sobre ellos en México fueron factores de peso para que, a pesar de haber sido liberados y haber obtenido la protección del Estado mexicano, los asilados permanecieran en el país bajo un clima de "terror total".

No estábamos en libertad: salimos de allá [del aeropuerto] con la policía mexicana, nos dejaron en un hotel. Al día siguiente distribuyeron alguna ropa, algún dinero, nos llevaron para hacer el documento, para obtener el asilo en México. Y mientras estábamos allá [en México], los quince, salíamos en grupo, sólo en grupo y escoltados por ellos. Y la recomendación era no salir. Y cuando salíamos había dos, tres carros siguiendo [...] Decían que había de todo: KGB, SNI, CIA [...] Era un clima de terror total, de control total. Tanto, que realmente evitábamos salir. ${ }^{39}$

Los agentes Javier Mancera Fuentes R. y Jorge L. Bustos Chavarría estuvieron a cargo de la vigilancia de los asilados brasileños instalados en el Hotel del Bosque. Cada día enviaban a sus superiores reportes cronológicos sobre las actividades cotidianas que desempeñaban y las visitas que recibían, así como de las entrevistas que concedían a medios nacionales e internacionales y hasta el tipo de revistas que guardaban en sus habitaciones. Por ejemplo, el día 12 de septiembre, al final de su reporte agregaron: "En el cuarto 412, del Hotel del Bosque, ocupado por los asilados João Leonardo da Silva y Ricardo

Informações do Ministério da Justiça resguardado por el Arquivo Nacional, así como de diversos archivos en otros países. El espionaje brasileño en el exterior se llevaba a cabo mediante la infiltración de agentes, violación de correspondencia, intercambio de informaciones con otros órganos de inteligencia y observación permanente de los exiliados. Viz Quadrat, "Muito Além das fronteiras", pp. 315-328.

39 Testimonio de Ricardo Vilas en DA-Rin, Hércules 56, p. 43. 
Zarattini se encontraron las siguientes revistas: China Reconstruye, U.R.S.S, Prensa Latina."40

Durante los días que estuvieron en México, los brasileños recibieron gran apoyo moral. Las visitas no pararon, especialmente de la comunidad de asilados brasileños que había llegado a México cinco años atrás, en la coyuntura del golpe en 1964, pero también de ciudadanos mexicanos, algunos estudiantes de la Facultad de Economía y otros elementos de "extrema izquierda de filiación trostkista”, según reportaron los agentes de Gobernación. ${ }^{41}$

Sin embargo, nada desvaneció el terror bajo el que vivieron aquellos días. Sabían que la humillación de la que había sido objeto el gobierno militar los colocaba en una situación de vulnerabilidad total, a ellos en México y a sus familiares en Brasil. La pena del banimento les había despojado de su nacionalidad y del derecho a volver a su país. En otras palabras, los había convertido "legalmente" en desterrados y apátridas.

El banimento era una condición que los distinguía entre otros exiliados; un castigo que además de impedirles volver a su país tenía el objetivo de marcarlos en el exterior como delincuentes que amenazaban la seguridad nacional, en un contexto en el que ese concepto tenía implicaciones hemisféricas, es decir, se ligaba a la seguridad de Estados Unidos y del bloque occidental, que durante la Guerra Fría impulsaba una alianza de defensa contra la "subversión enemiga". El banimento era una especie de advertencia hacia los países que compartían sus "preocupaciones hemisféricas" ${ }^{2}$ y una medida represiva en el exterior que

40 DFS, "Actividades de los asilados políticos brasileños", ciudad de México, 12 de septiembre de 1969, AGN, galería 1, DFS, exp.11-155-69. L. 1.H. 139. ${ }^{41}$ DIPS, "Declaraciones de los asilados políticos provenientes del Brasil...", México, D. F., 7 de septiembre de 1969, AGN, DIPS, c. 1746 “A”, exp. 4, p. 287.

42 Borges, "A Doutrina de Segurança Nacional e os governos militares", p. 24. 
pretendía obstruir la movilidad, la actividad, el derecho de asilo, la libertad, la vida de los desterrados.

En México, el gobierno de Díaz Ordaz los había asilado, pero el esquema de control que impuso sobre ellos les impedía tener una sensación de seguridad que les permitiera considerar la permanencia en México, como relata Ricardo Vilas: "En México no había condiciones para quedarnos, la situación era muy inestable, no nos sentíamos tranquilos. Teníamos miedo de un atentado [...] No teníamos sensación de seguridad en México". ${ }^{43}$

Por otro lado, de acuerdo con el líder sindical, José Ibrahim, durante el trámite migratorio que formalizó el asilo, el gobierno mexicano había dejado claro que se trataba de una concesión temporal y que no podrían permanecer en México durante mucho tiempo.

No nos podíamos quedar en México. El gobierno mexicano ya había avisado que estábamos allí por una cuestión de solidaridad; fue un acto humanitario del gobierno mexicano recibirnos, hasta porque estaba en juego la vida del embajador... El gobierno mexicano aceptó recibirnos, pero dejó claro que era de paso, que nadie se quedaría allá. Nosotros teníamos que ver cuál sería nuestro destino, nos tocaba a nosotros resolverlo $[\ldots]^{44}$

Por las características descritas, el asilo que el gobierno de México concedió a este grupo de brasileños parece haber sido más una medida de contención en el marco de una política continental de contrainsurgencia que un acto humanitario, como deberían ser todos los relacionados con la institución del asilo político.

Las peculiaridades del asilo que se les ofreció en México, sin embargo, no resultaron un problema para los asilados, pues

43 Testimonio de Ricardo Vilas, en DA-Rin, Hércules 56, p. 43.

${ }^{44}$ Testimonio de José Ibrahim en DA-RIN, Hércules 56, p. 104. 
no había entre ellos gran interés por permanecer en este país. La prioridad de la mayoría no era encontrar el mejor lugar para vivir el destierro, sino el lugar idóneo para preparar el regreso clandestino a Brasil y derrocar a la dictadura militar. La liberación bajo el esquema del secuestro les había generado un enorme compromiso con el regreso a su país y con sus organizaciones. Además, en algunos de ellos, el éxito de aquella operación había alimentado la percepción-equivocada, como se demostró dramáticamente pocos meses después- de que la revolución y la caída de la dictadura en Brasil estaban más cerca que nunca. ${ }^{45}$

De acuerdo con sus propias declaraciones, los asilados nunca vieron en México un lugar propicio para preparar el regreso a Brasil. En conjunto y de manera individual, siempre fueron enfáticos en señalar que no tenían intención de hacer de México el centro de su actividad política. "Seremos muy respetuosos de las leyes mexicanas", advirtieron una y otra vez ante la prensa.

Por otro lado, el ambiente enrarecido fortalecía algunas advertencias que antiguos exiliados brasileños les hacían respecto a las dificultades y los inconvenientes de vivir en México, como la que detectaron agentes de Gobernación del sacerdote brasileño Francisco Lage, quien les habría comentado que "en México existía también una dictadura semejante a la de Brasil”. ${ }^{46}$

Finalmente, tres semanas después de haber aterrizado en México hubo una gran deliberación en el grupo para decidir hacia dónde debían ir. Mediante una votación decidieron que el mejor lugar para cumplir sus objetivos sería Cuba, la referencia geopolítica de la resistencia en aquellos años. Allá, los que militaban en organizaciones armadas esperaban recibir entrenamiento militar, establecer un puente de comunicación con

45 Testimonio de Ricardo Vilas, en DA-Rin, Hércules 56, p. 43.

46 DIPS, "Declaraciones de los asilados políticos provenientes del Brasil...", México, D. F., 7 de septiembre de 1969, AGN, DIPS, c. 1746 “A”, exp. 4, p. 287. 
sus organizaciones y preparar el regreso clandestino a su país para lograr, por la vía armada, la caída de la dictadura militar brasileña. Otros tenían la intención de hacer un puente desde La Habana para viajar a un tercer país de asilo, como fue el caso del viejo militante comunista Gregorio Bezerra, que había llegado a México con un cáncer avanzado, y de Cuba siguió su viaje a Moscú, donde pasó el resto de su exilio.

Gracias al contacto que Flávio Tavares, uno de los asilados, había tenido previamente en Brasil con el entonces embajador de Cuba en México, Joaquín Hernández, el grupo pudo hacer contacto con esa embajada para solicitar asilo político. El gobierno revolucionario cubano los acogió y expidió la documentación pertinente para que realizaran el viaje.

El 29 de septiembre, 13 de los 15 brasileños se despidieron de México y volaron hacia La Habana. ${ }^{47}$ El estudiante Ricardo Vilas no viajó a Cuba porque, antes de partir, sus compañeros lo desligaron de la organización argumentando que no tenía el “nivel ideológico" para entrenar y volver a Brasil en un esquema de lucha armada. Pocos meses después viajó a Francia ${ }^{48}$ con un documento de viaje emitido por el gobierno de México que era válido únicamente durante diez días para dirigirse a ese país. Para obtenerlo, Vilas Boas, tuvo que renunciar previamente al asilo político que le había otorgado el Estado mexicano. ${ }^{49}$

47 DFS, "Se informa sobre salida de asilados brasileños a La Habana", ciudad de México, 29 de septiembre de 1969, AGN, galería 1, DFS, exp. 11-155-69. L. 1.H. 184-185.

48 Testimonio de Ricardo Vilas, en DA-Rin, Hércules 56, pp. 43-44.

49 Miguel Domínguez Loyo, "Oficio bueno para salir definitivamente a la persona que se cita de nacionalidad brasileña”, México, 6 de enero de 1970, AHSRE, exp. III-5714-11. Aunque en el archivo de la SRE sólo se encontró registro del documento emitido a Vilas Boas, es muy probable que los 13 que salieron a Cuba hayan recibido un documento similar luego de renunciar al asilo político en México. Esos documentos de viaje se expidieron a varios brasileños asilados desde 1964. Véase Morales MuÑoz, El exilio brasileño en México, pp. 139-140. 
El periodista Flávio Tavares fue el único que permaneció en México hasta $1974 . .^{50}$ En aquella deliberación, donde la mayoría del grupo había votado por renunciar al asilo en México y dirigirse a Cuba, él había propuesto que se quedaran, pues consideraba que en este país podrían establecer un puente de comunicación más efectivo con Brasil, en cambio en Cuba se aislarían demasiado. Sin embargo, nadie compartió su visión.

Durante los 22 días que estuvieron en México, el grupo de asilados denunció al régimen militar brasileño en cada oportunidad que tuvo. En el único comunicado que redactaron de manera conjunta y que leyeron al día siguiente de su llegada al país en el lobby del Hotel del Bosque, aprovecharon la vasta presencia de reporteros de medios de comunicación nacionales e internacionales para denunciar el uso sistemático de la tortura en Brasil, y para explicar que acciones como la del secuestro del embajador estadounidense, en el que ellos habían sido liberados, eran producto del cuadro de violencia que el poder militar había creado en ese país.

Manteniéndose en el poder a costa de las armas y, a través de la intervención en las fábricas, en el campo y en las escuelas, impidiendo al pueblo formular su propio destino, la dictadura militar implantó un clima de tensión, ansiedad, inseguridad y violencia, extensivo a todos los niveles sociales en que se verifican conflictos. La tortura es ahora instrumento usual en nuestro país.

50 Flávio Tavares era el único del grupo que hablaba español. Durante sus primeros años en México trabajó como traductor del portugués al español en la empresa de doblajes Servicio Internacional de Sonido S. A. del empresario Enrique Candiani. En 1973 se incorporó como reportero del periódico Excelsior, donde también había empezado a colaborar como traductor. En 1974 decidió renunciar al asilo en México y dirigirse a Buenos Aires, donde trabajó varios años como corresponsal de ese periódico mexicano. Conversación con Flávio Tavares, Porto Alegre, Brasil, 30 de noviembre de 2013, y Tavares, Memórias do esquecimento. 
Muchos murieron en las cárceles, donde millares padecen y se angustian con su propio sufrimiento de prisioneros y con las limitaciones de todo el pueblo brasileño, privado del derecho de organizarse para establecer las bases del desarrollo. ${ }^{51}$

Denunciaban, además, la desnutrición, el desamparo social, el desempleo, la injusta distribución de la tierra y el latifundio como complementos del cuadro de violencia que prevalecía en su país, y acusaban que la dictadura había desarrollado sus métodos más refinados de violencia en la represión a los movimientos estudiantiles a los que había puesto al margen del proceso institucional creando una natural resistencia activa en forma de movimientos orgánicamente estructurados, exteriorizada por las formas más distintas y particulares de protesta.

Concluían con la promesa de volver para continuar la lucha que los había conducido al destierro: “Distantes de nuestra patria permanece mientras tanto nuestro compromiso con el pueblo brasileño en la lucha contra la dictadura, el imperialismo y todas las formas de explotación económica y opresión política, porque solamente nos consideraremos libres en definitiva cuando libre sea todo el pueblo brasileño". ${ }^{52}$

A pesar de haber tenido una experiencia de asilo bajo estrecha vigilancia y control policial, incierta y breve, hacia el gobierno de México y los mexicanos este grupo de asilados sólo tuvo expresiones de agradecimiento por la hospitalidad y la solidaridad que dijeron haber recibido en este país.

La sorprendente operación de intercambio de 15 presos políticos por el embajador Burke Elbrick intensificó el proceso de

51 DFS, “Conferencia de prensa de los 15 asilados políticos brasileños”, ciudad de México, 8 de septiembre de 1969, AGN, galería 1, DFS, exp.11-155-69. L. 1.H. 70-77.

52 DFS, “Conferencia de prensa de los 15 asilados políticos brasileños”, ciudad de México, 8 de septiembre de 1969, AGN, galería 1, DFS, exp.11-155-69. L. 1.H. 70-77. 
represión en Brasil. Las organizaciones armadas fueron cercadas cada vez más por los órganos de represión hasta que fueron completamente desmanteladas. Pocas semanas después del rapto del diplomático estadounidense, más de 350 personas fueron enviadas a prisión y alrededor de 600 fueron detenidas para ser interrogadas. ${ }^{53} \mathrm{El} 4$ de noviembre de 1969, fue asesinado en São Paulo Carlos Marighella, el dirigente de la ALN, la organización revolucionaria más importante de ese momento.

La detención de los principales dirigentes y de buena parte de los militantes de las diferentes organizaciones armadas condujo a muchas de ellas a recurrir a la estrategia del secuestro con el objetivo de contener su desmantelamiento. El 11 de marzo de 1970, seis meses después de la captura del embajador de Estados Unidos, la organización Vanguarda Popular Revolucionária (VPR) capturó al cónsul de Japón en São Paulo, Nabuo Okuchi, con el objetivo central de liberar y enviar al exilio a dos de sus dirigentes destacados, Chizuo Ozava y Diógenes José Carvalho de Oliveira y tres presos políticos más.

Los gobiernos de Brasil y de Japón solicitaron al de México conceder nuevamente asilo a los cinco "elementos subversivos" 54 que debían ser liberados. El gobierno de Díaz Ordaz accedió aclarando, por medio de un boletín de prensa que, "Al igual que en los casos ocurridos en los últimos meses, la decisión del Primer Magistrado estuvo inspirada fundamentalmente en su propósito de no negar a dos países amigos, la asistencia que ambos solicitaron en una situación en que peligraba una vida humana". ${ }^{55}$

El domingo 16 de marzo de 1970 aterrizaron en la ciudad de México: Chizuo Ozava, militante destacado de vPr; Otâvio

53 Pinheiro Machado, Os exiliados, pp. 87-90.

54 Embajada de Brasil en México, "Nota número 40”, Ciudad de México, 13 de marzo de 1970, AHSRE, exp. 5714-11 (4 $4^{\text {a }}$ parte).

55 Secretaría de Relaciones Exteriores, "Boletín de prensa”, Tlatelolco, D. F. 13 de marzo de 1970. AHSRE, exp. 5714-11 (4 ${ }^{\mathrm{a}}$ pare). 
Ângelo, dirigente de ALn, Diógenes José Carvalho de Oliveira, militante de VPR; Maurina Borges da Silveira o "madre Maurina", religiosa franciscana acusada de proteger y colaborar con las Fuerzas Armadas de Liberación Nacional por haberles prestado un espacio para realizar una reunión, y Damaris Oliveira Lucena, militante de VPR, quien salió del país, como exigió la organización, con sus tres hijos, Adilson y Denise, gemelos de nueve años, y Ángela de Oliveira Lucena, de tres.

Antes de aterrizar en México, la embajada mexicana en Brasil envió a la Secretaría de Gobernación una relación en la que advertía sobre la militancia y la vinculación de los presos que llegarían a México con las organizaciones "terroristas" brasileñas, ${ }^{56}$ basada en información que sobre las actividades de los mismos le reportó el Ministerio de Relaciones Exteriores de Brasil.

Procedentes de São Paulo, los prisioneros y los tres niños viajaron en un avión comercial de la línea aérea Cruzeiro Do Sul, custodiados por 10 agentes de la policía brasileña. Los tres hombres adultos fueron atados de pies y manos durante el trayecto. ${ }^{57}$ Cuando pisaron territorio mexicano ya se había emitido en Brasil el Decreto No. 66.319 que desterraba a los cinco prisioneros liberados y les negaba la nacionalidad por medio de la pena del banimento.

El gobierno brasileño había solicitado la cooperación del mexicano en el sentido de intentar que esta vez la llegada de los cinco nuevos banidos fuera cercada con el mayor sigilo..$^{58}$ Sin embargo, esta nueva acción de liberación forzada volvió a

${ }^{56}$ DFS, "Memorandum para información del señor presidente de la República”, Distrito Federal, 14 de marzo de 1970, AGN, galería 1, DFS, exp. 11-55970, L.1. H. 218-220.

57 Fernando Gutiérrez Barrios, "Arribo a México de los asilados políticos brasileños...”, Distrito Federal, 15 de marzo de 1970, AGN, galería 1, DFS, exp. 11-155-970, L. 1. H. 221-224.

58 Embajada de Brasil en México, "Nota número 40", Ciudad de México, 13 de marzo de 1970, AHSRE, exp. III-5714-11 [s/n]. 
ser noticia a nivel internacional, como lo demuestran los múltiples recortes de prensa alusivos a la llegada a México de los presos brasileños, enviados a la cancillería mexicana desde varias embajadas de México en países de Europa, África, Asia y América Latina.

\section{Foto 3}

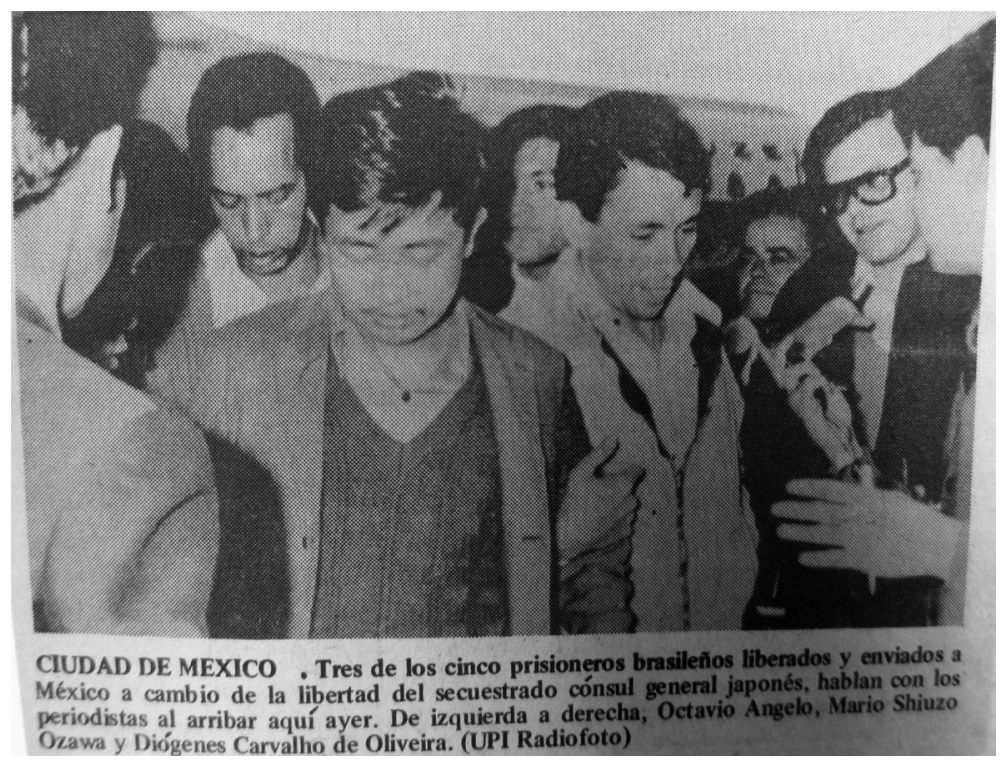

El 16 de marzo de 1970 aterrizaron en la ciudad de México cinco presos políticos brasileños intercambiados por el cónsul japonés Nabuo Okuchi. AHSRE, exp. 5714-11 (4a parte).

En México, el arribo de los brasileños convocó a un grupo de reporteros y fotógrafos de diferentes diarios locales ante quienes los asilados denunciaron, como lo hizo el grupo que le antecedió, la violencia y la violación de todas las garantías individuales que ejercía el régimen militar brasileño con el objetivo de "ahogar todas las protestas del pueblo en demanda de justicia". 
En el aeropuerto, los presos liberados fueron recibidos efusivamente por un grupo de brasileños exiliados en México, entre ellos, el padre Francisco Lage, quien acudió al lugar con dos religiosas pertenecientes a la comunidad franciscana del Distrito Federal con la intención de solicitar al jefe de Población, Julio Cerecedo, autorización para llevarse al convento a la religiosa que venía en el grupo, Maurina Borges da Silveira, lo que se les impidió en ese momento debido a que los recién llegados tenían que acudir al día siguiente a la Dirección General de Población en la Secretaría de Gobernación para concluir el trámite migratorio.

La Embajada de México en Brasil remitió a Relaciones Exteriores información detallada sobre las actividades políticas y la militancia de cada uno de los asilados, señalando a Diógenes José Carvalho como "el de más cuidado", en tanto que el embajador de Brasil en México, João Baptista Pinheiro, solicitó a la DFs que le brindara servicios de seguridad, tanto en su residencia como en la sede de la embajada, porque temía "actos de represalia por parte de elementos afines a los terroristas brasileños" que llegaban a México. ${ }^{59}$ Es posible que el embajador brasileño realmente temiera por su seguridad en México, después de todo los funcionarios diplomáticos eran en ese momento el blanco de las organizaciones revolucionarias. Sin embargo, la petición de medidas de protección en México parecía más orientada a remarcar ante las autoridades mexicanas la "peligrosidad" de los asilados para incidir en el trato que éstos recibirían en este país.

Como en el caso de los 15 anteriores, los cinco banidos fueron hospedados en el Hotel del Bosque de la ciudad de México donde permanecieron bajo estrecha vigilancia de los agentes de la DFs, Fausto Bado de la Torre, Othón Viloria Vázquez y Leopoldo Valdez Moreno, quienes incluso controlaban el

${ }^{59}$ Memorándum al director de la DFS, 14 de marzo de 1970, México, D. F., AGN, galería 1, DFS, exp. 76-27-70, L1. H.12. 
Foto 4

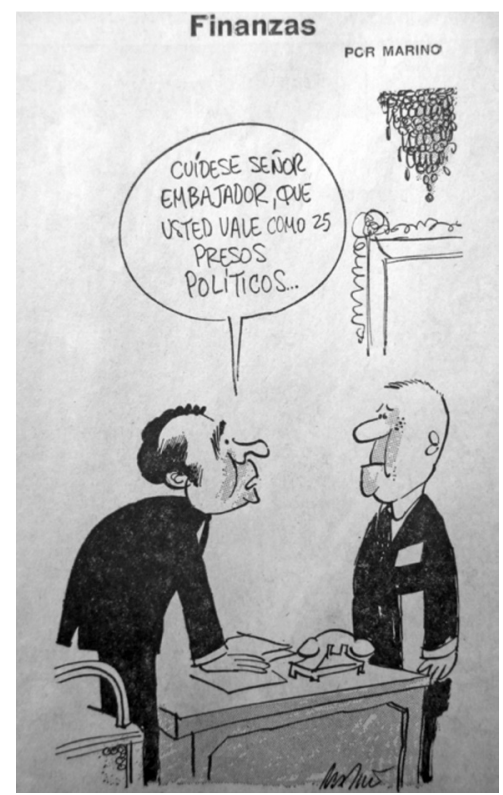

Caricatura de Marino publicada en Excelsior (8 sep. 1969), p. 6-A.

contacto de éstos con los reporteros que acudían al lugar para entrevistarlos. ${ }^{60}$

La Secretaría de Gobernación envió a un médico para revisar a los presos liberados pues, según el reporte, todos mostraban signos de tensión nerviosa; la niña Denise presentaba además un cuadro de amigdalitis y Chizuo Ozava tenía varias lesiones producidas por las torturas que había recibido en

60 La reportera Chris Angelo de Associated Press escribió en una nota reproducida en un diario panameño que "un guardia de seguridad mexicano, vestido de civil, estaba con el grupo y rehusó permiso para que la reportera hablara con ellos”. En Chris Angelo, "Piensan permanecer en México los cinco presos enviados desde el Brasil”, La estrella de Panamá (17 mar. 1970). Consultado en AHSRE, exp. 5714-11 (IV). 
prisión y por un accidente automovilístico tras el cual había sido detenido en Brasil.

Al día siguiente, los brasileños acudieron a la Secretaría de Gobernación para concluir el trámite migratorio en la Subdirección de Población, donde otros asilados brasileños, Victor Papandreu, Isaac Scheinvar y Selva Correa Mendes, fueron citados por el titular de esa oficina, Miguel Domínguez Loyo, para fungir como intérpretes entre los recién llegados y los funcionarios mexicanos. ${ }^{61}$

Recibieron un documento donde se indicaba su calidad de no inmigrantes y se establecía un plazo de 30 días para demostrar fehacientemente que disponían de los medios económicos para subsistir en México. ${ }^{62}$

En ese contexto se presentó en la Secretaría de Gobernación el obispo de Cuernavaca, Sergio Méndez Arceo, quien realizó las gestiones ante las autoridades mexicanas para poder conducir a la religiosa Maurina Borges a un convento franciscano bajo su tutela, permiso que logró obtener pocos días después; ésta pudo entonces abandonar el hotel y trasladarse a la capital morelense. ${ }^{63}$

${ }^{61}$ DFS, “Actividades de los asilados políticos brasileños...”, ciudad de México, 16 de marzo de 1970, AGN, galería 1, DFS., exp. 11-155-970, H. 233-235. ${ }^{62}$ Dirección General de Población, 31 de marzo de 1970, AHSRE, exp. III$5714-11[\mathrm{~s} / \mathrm{n}]$.

${ }^{63}$ En las décadas de 1960 y 1970 Méndez Arceo se convirtió en un actor político de gran relevancia en México por su visión renovadora de la Iglesia católica y su cercanía con los sectores más desprotegidos de la sociedad, como los obreros, los campesinos, los presos políticos y, como se muestra en este caso, los exiliados. Confrontado con los postulados de las altas jerarquías de la Iglesia católica mexicana, fue apodado despectivamente por los sectores conservadores mexicanos como "el obispo rojo" por su actividad como promotor de una propuesta cristiana centrada en la unidad de los pueblos latinoamericanos y la reivindicación de los sectores marginados de la sociedad que sufrían las consecuencias de gobiernos autoritarios y del imperialismo estadounidense. En ese contexto debe entenderse su acercamiento con este grupo de exiliados y la ayuda que prestó especialmente a la religiosa brasileña. 
De acuerdo con los reportes de la DFs, los asilados brasileños establecieron contacto con asilados guatemaltecos que se encontraban hospedados en el mismo hotel, y recibieron la visita recurrente de otros brasileños exiliados en México como Flávio Tavares, que había llegado recientemente en el grupo de los 15, las familias Scheinvar y Taylor, asiladas en México desde 1964, al igual que Victor Medeiros, Selva Correa Mendes, Vitor Luíz Papandreu, Peregrino Romay, el sacerdote católico Francisco Lage, Antonio Quiñones Peyre, Marcelo Abramo, Etelvina Correa, João Barbosa do Nascimento, Claudio Colombani y Francisco Julião. ${ }^{64}$

La policía mexicana también registró la visita de personas de nacionalidad mexicana, como Manuel Dávalos y Pilar Reyes Rentería, que acudieron a ofrecer ayuda económica a los asilados y algunos juguetes para los niños que habían llegado con ellos.

Durante los días que permanecieron en México, los cinco canjeados tuvieron un contacto constante con diferentes medios de comunicación, ante quienes denunciaron que Brasil padecía "un dominio absoluto de los Estados Unidos de Norteamérica" y un régimen militar implantado por ellos; explicaron que la misión de las organizaciones revolucionarias brasileñas era "liberar al pueblo de Brasil del imperialismo yanqui", y denunciaron la existencia de 12000 presos políticos; dijeron que desde 1964 no existía democracia alguna en su país, y que la única subversión era la del régimen militar. ${ }^{65}$

Ante los medios de comunicación los asilados, militantes de VPR, reconocieron que en Brasil habían participado en acciones violentas, como asaltos a bancos, con el objetivo de sostener a la

${ }^{64} \mathrm{DFS}$, “Arribo a México de los asilados políticos brasileños...”, 15 de marzo de 1970, ciudad de México, AGN, DFS, galería 1, exp. 11-155-970, L1. H. 221-224.

${ }^{65}$ Fernando Gutiérrez Barrios, "Actividades de los asilados políticos brasileños...”, México, D. F., 19 de marzo de 1970, AGN, DFS, versión pública, “Asilados políticos brasileños”, Leg. único, c. 297, p. 233. 
organización, pero intentaron explicar y justificar los motivos de ese tipo de violencia política: "No se puede precisar hasta qué punto sean efectivos los métodos guerrilleros; pero sí es seguro que es la única manera de combatir al régimen”, expresó Diógenes José Carvalho de Oliveira.

En varias ocasiones agradecieron las atenciones del gobierno y del pueblo de México y aseguraron que como extranjeros respetarían las leyes mexicanas, lo que significaba que se abstendrían de realizar actividades políticas en territorio mexicano.

Quince días después de su llegada a México los canjeados -con excepción de la madre Maurina, que se había trasladado a Cuernavaca, donde pasó los 14 años de su exilio-decidieron seguir los pasos del grupo de banidos que les antecedió: acudir a la embajada de Cuba en México para solicitar su traslado a ese país. ${ }^{66}$ Una vez aceptados, renunciaron al asilo político en México y el 27 de marzo de 1970 Chizuo Ozava, Otávio Angelo, Diógenes José Carvalho de Oliveira, y Damaris Oliveira Lucena con sus tres hijos, abordaron un avión con destino a La Habana.

Aunque intentaron que su salida de México fuera bastante discreta, algunos reporteros lograron interceptarlos en el aeropuerto y cuestionarlos sobre los motivos de su renuncia al asilo político en México. Aseguraron que se debía específicamente a motivos de salud, pues la altura de la ciudad de México les ocasionaba fuertes malestares. ${ }^{67}$ Anunciaron también que desde Cuba lucharían en contra del gobierno de Brasil, que les había despojado de su nacionalidad. ${ }^{68}$

66 DFS, “Actividades de los asilados políticos brasileños...”, 25 de marzo de 1970, ciudad de México, AGN, DFS, galería 1, exp. 11-155-970, L.1. H. 289-292.

67 DFS, “Actividades de los asilados políticos brasileños...”, 27 de marzo de 1970, ciudad de México, AGN, DFS, galería 1, exp. 11-155-970 [s/n].

68 Luis de la Barreda Moreno, "Actividades de los asilados políticos brasileños”, Ciudad de México, 27 de marzo de 1970, AGN, DFS, versiones públicas “Papandreu Prekovski, Víctor Luis", leg. único, 294, p. 303. 
El gobierno de Díaz Ordaz favoreció el despliegue mediático que a nivel nacional e internacional se le dio a la llegada a México de los prisioneros políticos brasileños, como una oportunidad para refrendar la disposición de México a brindar protección a los perseguidos políticos, y una prueba de su apertura y de su vocación democrática. En ese sentido, la noticia de la renuncia al asilo político en México y el traslado a Cuba de la mayoría de ellos no resultó del todo agradable para el gobierno mexicano en términos políticos y propagandísticos. Sin embargo, al facilitar el viaje a Cuba también se liberaba de aquel grupo de brasileños desterrados, ligados en su mayoría a organizaciones revolucionarias brasileñas. Después de todo, la protección que el Estado mexicano les había concedido de manera excepcional no había sido motivada por el interés de garantizar su libertad y su bienestar sino, como el propio Díaz Ordaz lo declaró, por el interés de colaborar con gobiernos de países amigos a preservar dos vidas humanas: la del embajador estadounidense y la del cónsul de Japón. ${ }^{69}$

\section{PERSEGUIDOS EN “PATRIA AJENA”}

En el transcurso de 1970, la captura del embajador alemán, Ehrenfried Anton Theodor Ludwig von Holleben, en junio, y del embajador suizo, Giovanni Enrico Bucher, en diciembre, llevaron a la liberación de otros 110 presos políticos en Brasil: 40 en el primer caso, que fueron asilados por el gobierno de Argelia, y 70 en el segundo, que fueron trasladados a Chile, donde se empezaba a concentrar un gran número de brasileños. ${ }^{70}$ No

\footnotetext{
69 SRE, Memoria de la Secretaría de Relaciones Exteriores del 1 de septiembre de 1969 al 31 de agosto de 1970, p. 35.

70 En total, entre 1969 y 1970 las organizaciones políticas revolucionarias en Brasil forzaron por esa vía la liberación y el envío al exilio de 130 presos políticos del régimen militar que fueron banidos o expulsados del territorio brasileño.
} 
sabemos si en estas nuevas operaciones para la liberación de presos políticos México fue considerado como opción de asilo. No sería raro que esta vez el gobierno de Díaz Ordaz, en sus últimos meses, o el de Luis Echeverría, que tomó posesión como presidente el 1o de diciembre de ese año, ya no tuvieran la misma disposición para recibir a estos nuevos y numerosos grupos de desterrados, luego de que el 23 de mayo, en la víspera de la inauguración del Mundial de Futbol en México, dos asilados de origen brasileño secuestraran, con la ayuda de un joven mexicano, un avión comercial ${ }^{71}$ que despegó de Mérida para obligarlo a desviar el trayecto hacia La Habana. ${ }^{72}$

El hecho, al que Díaz Ordaz se refirió en su último informe como un acto de ingratitud, ${ }^{73}$ había tenido efectos muy negativos sobre la comunidad de asilados brasileños que radicaba en México. La Procuraduría General de la República sometió a interrogatorio a varios de ellos como parte de la investigación que se abrió en torno al caso y desde la prensa mexicana se alentó una actitud de rechazo hacia los asilados de origen brasileño, a quienes acusaban de pretender convertir el derecho de asilo en un escudo protector de actos delictuosos.

Al finalizar el año de 1970 un total de 130 presos políticos brasileños había salido al exilio por medio de esa vía sui generis, concebida y ejecutada por las organizaciones revolucionarias brasileñas entre 1969 y 1970 . Todos los beneficiados habían sido castigados con la pena del banimento y el grupo más grande se había asilado en Chile.

71 La Procuraduría General de la República identificó a los exmilitares brasileños Víctor Luiz Papandreu y Selva Correa Mendes, asilados en México desde 1968, como los responsables del secuestro de la aeronave.

72 SNI, "Sequestro de aeronave mexicana por asilados brasileiros. Repercussão no México”, 30 de mayo de 1970, ANB, exp. DSI/664, SNIG/A0302016-1971. 73 SRE, Memoria de la Secretaría de Relaciones Exteriores del 1 de septiembre de 1969 al 31 de agosto de 1970, p. 10. 
En noviembre de 1970 ese país del Cono Sur inauguró el primer gobierno socialista que llegó al poder por la vía pacífica, convirtiéndolo en referencia para la izquierda latinoamericana. Por eso concurrieron a él exiliados de varios países de la región que estaban cercados por gobiernos dictatoriales, así como muchas otras personas interesadas en conocer de cerca la experiencia chilena. La comunidad de brasileños en Santiago llegó a ser de las más numerosas. ${ }^{74}$

En Chile muchos brasileños tuvieron una intensa militancia política pues en el gobierno de la Unidad Popular los extranjeros no tenían vedado el derecho a la participación política. ${ }^{75} \mathrm{Algu}-$ nos trabajaron activamente en el gobierno de Salvador Allende, otros lo hicieron desde los recintos académicos, y algunos otros, sobrevivientes de la guerrilla brasileña, intentaron revivir sus organizaciones revolucionarias que, para esos años, ya habían sido prácticamente aniquiladas en Brasil. ${ }^{76}$

En las primeras horas del 11 de septiembre de 1973 un levantamiento militar liderado por el comandante del Ejército, $\mathrm{Au}$ gusto Pinochet, puso fin a la experiencia socialista del gobierno y a la vida del presidente Allende. En pocas horas el terror se instaló en el país.

El gran proceso revolucionario que se vivía en Chile se transformó inmediatamente en persecuciones, allanamientos, detenciones masivas, desapariciones, tortura y muerte, no sólo en contra de quienes fueron considerados enemigos políticos, sino de muchas otras personas que aleatoriamente se convirtieron en víctimas del terrorismo de Estado desatado tras la declaración de estado de guerra invocado por los golpistas por medio de la Ley del Estado de Sitio.

74 Norambuena, Palomera y López, "Brasileños en Chile durante la dictadura militar”, p. 458.

75 Rojas Mira, “El exilio político chileno”, p. 122.

76 Pinheiro Machado, Os exiliados, p. 100. 
La junta militar promovió una campaña contra los extranjeros, ${ }^{77}$ acusándolos de formar parte de un ejército de terroristas latinoamericanos ${ }^{78}$ a los que responsabilizaba de todo lo malo que estaba sucediendo en Chile, y llamaban a la población a denunciarlos advirtiendo que serían duramente castigados quienes fueran descubiertos protegiendo o encubriendo a alguno de ellos. Los extranjeros quedaron entonces en una situación sumamente vulnerable, así que inmediatamente comenzaron a buscar protección. Muchos la encontraron en las representaciones diplomáticas de sus propios países, pero no todos corrieron con la misma suerte. Los brasileños, por ejemplo, fueron abandonados completamente por su representante diplomático.

Varios países, como Argentina, Perú, Uruguay, trataron de recoger sus exiliados. Frente a la amenaza de muerte en las calles de Santiago se les ofrecía la alternativa de regresar a su patria, aun enfrentando procesos o prisiones.

A los brasileños no se les dio esa alternativa. Las puertas de la embajada permanecieron cerradas.

La visa de salida que se exigía para poder dejar el país era sistemáticamente negada por la embajada, aun a los que no tenían ningún envolvimiento político, incluso a mujeres y niños que habían ido a visitar maridos y padres.

En lugar de ayudar a los brasileños en dificultades frente al estado de guerra civil desencadenado en un país extranjero, el gobierno de Médici se empeñó en agravar las condiciones de los compatriotas que allá se encontraban [...] algunos exiliados, aterrorizados, se

77 De acuerdo con el Comité de las Naciones Unidas de Ayuda para los refugiados chilenos, en la coyuntura del golpe se calculaba que había alrededor de cinco mil latinoamericanos asilados en Chile. Declaraciones publicadas por Excelsior (13 feb. 1974), tomadas de ARRIOLA, "El acercamiento mexicanochileno", p. 543.

78 Pinheiro Machado, Os exiliados, p. 100. 
enfrentaron una vez más a los interrogatorios de los cuales pensaban haber escapado para siempre $[\ldots] .{ }^{79}$

En la representación mexicana, donde encontraron asilo cientos de ciudadanos chilenos, fueron protegidos también 43 brasileños, 14 de los cuales tenían la condición de banidos o desterrados, por haber salido al exilio en operaciones de intercambio por funcionarios diplomáticos llevadas a cabo por organizaciones revolucionarias. De hecho, entre los brasileños que se asilaron en la embajada mexicana en Santiago se encontraban algunos que ya habían estado asilados en México, como José Duarte Dos Santos y Otacilio Pereira Da Silva, en 1964, o casos más recientes, como los de Luis Travassos y Vladimir Palmeira, que habían llegado a México en la operación de intercambio por el embajador de Estados Unidos en 1969, y Diógenes José Carvalho de Oliveira, que en 1970 fue uno de los cinco que llegaron en el intercambio por el cónsul japonés.

Algunos otros de los brasileños que integraban ese grupo habían llegado a Chile en la operación de rescate más grande que organizaciones armadas brasileñas habían logrado en 1970 mediante el secuestro del embajador suizo, Giovanni Enrico Bucher, en la que liberaron y enviaron al exilio a 70 presos políticos.

Se trataba, pues, de un grupo de jóvenes brasileños que se encontraban exiliados en Chile; muchos de ellos militaban o habían militado en organizaciones armadas, y tras el golpe que terminó con el gobierno de la Unidad Popular se habían convertido en perseguidos políticos en su país de asilo. Enfrentaban ahora una doble persecución. La embajada de México los acogió, incluyendo a varios de sus familiares, y los trasladó a México, donde aterrizaron el 26 octubre de 1973 en el marco del solidario

79 Pinheiro Machado, Os exiliados, pp. 104-110. 
recibimiento que el gobierno de Luis Echeverría Álvarez ofreció a los asilados chilenos.

En esa crítica coyuntura, el gobierno militar de Brasil operó por medio de sus embajadas en diferentes países para intentar desalentar la concesión de asilo a los exiliados brasileños, especialmente a los desterrados o banidos, advirtiendo que se trataba de "subversivos", "secuestradores" con diferente grado de peligrosidad.

No se puede saber si esas advertencias influyeron, pero en esa coyuntura los brasileños encontraron serias dificultades para obtener asilo en varios países latinoamericanos. ${ }^{80}$ Hasta ahora se han podido documentar casos en los que los gobiernos de Argentina y México otorgaron el asilo diplomático en sus embajadas de Santiago, pero negaron el asilo territorial una vez que los asilados estuvieron en sus territorios.

En México, los brasileños, así como exiliados de otros países latinoamericanos procedentes de Chile, obtuvieron permisos para permanecer en el país en calidad de "turistas" o "en tránsito", pero pocas semanas después fueron notificados de que en un plazo de 30 días tendrían que abandonar el país ${ }^{81}$ bajo el argumento de que no eran sujetos de asilo aquellos que eran perseguidos en una patria ajena, por lo que tendrían que buscar otro país de asilo.

Ese argumento, a pesar de haber sido utilizado por funcionarios del gobierno mexicano ante los exiliados latinoamericanos procedentes de Chile para negarles el asilo territorial en México, no tenía ningún sustento jurídico, sin embargo, se adecuaba a la política de asilo que el presidente Echeverría había delineado desde la primera declaración que hizo en relación con el golpe de Estado en Chile la misma noche de aquel 11 de septiembre.

80 Rollemberg, Exílio, p. 87.

81 “Refugiados brasileiros no México", 20 de noviembre de 1973, ANB, “Proyecto Memorias Reveladas”, fondo: CISA, exp. BR AN BSB VAZ 115_0056. 
[...] El embajador de México en Chile ha recibido instrucciones de otorgar de inmediato, a la familia Allende, si lo solicita, el asilo diplomático que le será concedido con la afectuosa hospitalidad del pueblo mexicano; y el propio asilo, a cualquier persona de nacionalidad chilena cuya protección proceda, poniéndola bajo la protección de la bandera mexicana. ${ }^{82}$

Como observa Carlos Arriola, en esta declaración el presidente Echeverría ofrece el asilo "a todos los chilenos, con exclusión tácita de los latinoamericanos que se encontraban en Chile". ${ }^{83}$ Unas semanas después, como para exculpar al gobierno de México, el propio canciller mexicano declaró durante su participación en la Asamblea General de las Naciones Unidas que era "alentadora" la información proporcionada por el secretario general de la onu en el sentido de que el Ministerio de Relaciones de Chile había ofrecido seguridades sobre la suerte de los extranjeros que se encontraban en dicho país, y en diciembre de ese mismo año el subsecretario de Relaciones Exteriores, Rubén González Sosa, reconoció en declaraciones publicadas por el periódico El Día que algunas personas no chilenas que habían recurrido al asilo habían estado en México sólo de paso a otros países. ${ }^{84}$

En efecto, de acuerdo con el testimonio del profesor Wilson Barbosa, desterrado del territorio brasileño en enero de 1971 por haber sido liberado y enviado al exterior en intercambio de la vida del embajador suizo Giovanni Enrico Bucher, y uno de los

82 Declaración emitida por la Presidencia de la República a las 20:30 horas del 11 de septiembre de 1973 reproducida por Excélsior el 12 de septiembre de 1973, tomada del texto de Arriola, "El acercamiento mexicano-chileno", p. 534.

83 Arriola, “El acercamiento mexicano-chileno", p. 534.

84 El discurso del canciller mexicano ante la asamblea de la ONU se publicó en El Día (4 oct. 1973) y las declaraciones de González Sosa en El Día (11 dic. 1973). Tomadas de Arriola, "El acercamiento mexicano-chileno", p. 543. 
que llegó a México entre aquel grupo de brasileños que fueron asilados en la embajada mexicana en Santiago, al llegar a México la determinación del gobierno fue de únicamente dar asilo a los ciudadanos de origen chileno:

Cuando llegamos hubo la orden de que sólo los chilenos tendrían asilo político, porque Echeverría se decía amigo de Salvador Allende y estaba socorriendo al pueblo de Chile, entonces ellos podían quedarse, los demás que venían juntos no podían quedarse porque eran visita de Chile o visitas de México, entonces México no tenía nada con ellos, y eran considerados en tránsito, México les había ayudado a salir de Chile, los había protegido a través de su embajada, pero a la hora de llegar a México ya podían irse a otra parte $[\ldots]{ }^{85}$

Marijane V. Lisboa, también integrante del grupo, dejó testimonio de aquella gran decepción.

Pensábamos que íbamos a tener asilo en México. Llegamos y fuimos alojados en un hotel. En la primera semana los asistentes sociales del gobierno ya nos encaminaban para trabajos, estudios, renta de casas. Yo hice mi matrícula en la Universidad de México y ya estaba con un empleo a la vista. Ahí vino entonces la noticia de que el gobierno mexicano sólo daría asilo para los chilenos, o sea, según ellos, para personas perseguidas en su patria. Nosotros éramos personas perseguidas por "patria ajena” y por eso no teníamos derecho. Quedamos arrasados, porque nadie tenía las mínimas ganas de andar recorriendo el mundo entero en busca de asilo $[\ldots] .{ }^{86}$

Ante la negativa del gobierno mexicano, varios integrantes del grupo de brasileños decidieron impulsar un movimiento

${ }^{85}$ Conversación con Wilson Barbosa do Nascimento, São Paulo, Brasil, 10 de diciembre de 2015.

${ }^{86}$ Uchôa Cavalcanti y Ramos (orgs.), Memórias do exílio, pp. 250-252. 
para quedarse en México buscando apoyo internacional y de la propia sociedad mexicana para conseguir que las autoridades finalmente les otorgaran el asilo territorial.

En esa coyuntura, organizaciones estudiantiles y universitarias en México difundieron un manifiesto dirigido a la opinión pública por medio del cual demandaban al gobierno mexicano respetar la tradicional política de asilo del país y abrir las puertas a todos los latinoamericanos perseguidos.

Actualmente se ha asilado y dado facilidades a los hermanos chilenos, pero no así a compañeros sudamericanos brasileños, uruguayos, bolivianos, a los cuales se les ha emplazado a abandonar el país, en contra de la tradicional hospitalidad del pueblo mexicano.

Ante estos acontecimientos las organizaciones abajo firmantes, y las 10,000 personas cuyos nombres y rúbricas aparecen, demandamos a las autoridades competentes, el asilo político de los compañeros latinoamericanos que lo soliciten. ${ }^{87}$

Sin embargo, en contra de los brasileños y de otros latinoamericanos procedentes de Chile que buscaron asilarse en México, también jugó la coyuntura política interna que apenas unos días después del golpe entró en un clima particular de tensión tras el asesinato del poderoso industrial Eugenio Garza Sada, ocurrido el 17 de septiembre de 1973 en Monterrey, durante un intento fallido de secuestro por parte de una célula de la Liga Comunista 23 de Septiembre. El hecho, que acentuó la confrontación de varios sectores de la iniciativa privada con el presidente Echeverría, también desató una ola de ataques contra su gobierno por parte de los sectores conservadores del país en los que se intentó asociar ese tipo de actos violentos con la política que había asumido

${ }^{87}$ Firman como responsables Armando Jesús Villegas y Alfonso Piña Orozco. Una copia del manifiesto se localizó en los documentos del SNI, ANB, "Proyecto Memorias Reveladas”, fondo: CISA, exp. BR AN BSB VAZ 114a-0159. 
el gobierno de Echeverría frente a Chile, acusándolo de defender y solidarizarse con un gobierno calificado como "socialista" y "marxista” y aceptando asilar en México a elementos "no gratos", ${ }^{88}$ lo que quizá pudo influir en la decisión de Echeverría de no extender el asilo ofrecido a los chilenos a otros latinoamericanos procedentes de Chile, mucho menos a aquellos que habían sido desterrados de Brasil por haber salido al exilio en operaciones ejecutadas por organizaciones guerrilleras.

En ese contexto, la Secretaría de Gobernación, disgustada también por la movilización que se impulsó para conseguir asilo en México, en la que participaron sectores de la sociedad mexicana, no se limitó a negar el asilo territorial a los brasileños, sino que además recurrió a la intimidación violenta para obligarlos a abandonar el país, como lo describen dos testimonios que califican su paso por México como una experiencia "horrorosa y humillante".

El profesor Wilson Barbosa narra que a las seis de la mañana del día siguiente de haber visitado la Universidad, donde había conseguido dos ofertas de trabajo, fue requerido por la Secretaría de Gobernación:

Me fui caminando hasta allá y un tipo que ya había hablado con nosotros una vez anterior me preguntó: ¿qué fuiste a hacer a la universidad ayer?, yo dije, fui en busca de un trabajo, y a los gritos me dijo: ¡No vas a trabajar con Semo, no te vas a quedar en México, no vas a trabajar con Florescano, fuera, fuera, fuera!, ¡tienes que escoger un país a donde te vas y te vas inmediatamente de México! ${ }^{89}$

De acuerdo con Reinaldo Guarany:

88 Arriola, "El acercamiento mexicano-chileno", p. 540.

89 Conversación con Wilson Barbosa do Nascimento, São Paulo, Brasil, 10 de diciembre de 2015. 
Una noche nos llevaron a Gobernación o a algún lugar del Ministerio del Interior donde había también una estructura de la policía. Estábamos ahí, bajamos un piso y me sentaron en una silla, no sé cómo fue con los otros, pero había un tipo con una máquina de escribir y me dijo, bueno, ¿cuál es tu intención en México?, y yo contesté: pedir asilo político. Entonces empecé a escuchar gritos de un tipo ahí cerca, y el tipo que me cuestionaba me dijo, ¿y tú crees que México es el mejor lugar del mundo para quedarte?, y los gritos eran de alguien que estaba siendo torturado, nosotros conocemos eso, entonces yo le dije, mira, ahora yo estoy en duda de si éste es el mejor lugar, y contestó: mira, ustedes tienen que irse de México, mientras tanto pueden quedarse acá, pero llegará un tiempo que nuestra paciencia se terminará y los pondremos en un avión para donde sea $[\ldots] .{ }^{90}$

Ante la imposibilidad de conseguir el asilo en México y en una situación de gran desesperación, los brasileños integraron distintas comisiones dedicadas a recorrer las embajadas de diferentes países en la ciudad de México en búsqueda de un país de asilo, como reportó el agregado militar de la embajada de Brasil en México en diciembre de 1973.

Los refugiados brasileños que se encuentran en los Estados Unidos Mexicanos procedentes de Chile, después de la revolución del día 11 de septiembre de 1973 en aquel país, continúan buscando por todos los medios salir de México, una vez que este país ya informó oficialmente que no pretende mantenerlos como "asilados". ${ }^{91}$

90 Conversación con Reinaldo Guarany, Río de Janeiro, Brasil, 4 de abril de 2015.

91 Agregado de las Fuerzas Armadas en la Embajada de Brasil, "Refugiados brasileiros no México", México, D. F. 31 de diciembre de 1973, ANB, "Proyecto Memorias Reveladas”, exp. BR-AN-BSB-VAZ-115-0056. 
La negativa del gobierno mexicano a otorgarles asilo territorial no era la única dificultad que enfrentaban en aquel momento. La embajada brasileña operaba al mismo tiempo para impedir que consiguieran una visa para trasladarse a otro país, como se detalla en un informe del agregado militar brasileño dirigido a sus autoridades en Brasil.

El diplomático costarricense que atendió a los refugiados brasileños, inadvertidamente expidió el documento de "visa” con permiso para entrar a Costa Rica a uno de ellos (José Mariane Ferreira Alves). Una vez alertado, buscó un contacto con la embajada de Brasil y no atendió más a los refugiados, diciendo a los mismos que fueran a presentarse ante las autoridades brasileñas [... ${ }^{92}$

Al cabo de cinco o seis meses de intentar infructuosamente obtener asilo territorial en México, los brasileños provenientes de Chile terminaron por abandonar el país. La mayoría de ellos viajó a países europeos donde fueron recibidos en calidad de refugiados políticos.

A diferencia de los casos anteriores, los integrantes de este grupo no buscaron trasladarse a Cuba, donde algunos de ellos ya habían estado en algún momento de su exilio. El panorama político en América Latina había cambiado dramáticamente con el derrocamiento de Salvador Allende y, por otro lado, el objetivo de adquirir entrenamiento militar en la isla con la perspectiva de regresar a Brasil a combatir a la dictadura se había desvanecido, pues hacia 1973 la mayoría de las organizaciones armadas brasileñas habían sido prácticamente aniquiladas. ${ }^{93}$

92 Agregado de las Fuerzas Armadas en la Embajada de Brasil, "Refugiados brasileiros no México”, México, D. F. 31 de diciembre de 1973, ANB, “Proyecto Memorias Reveladas”, exp. BR-AN-BSB-VAZ-115-0056.

93 La perspectiva de regresar a Brasil para combatir a los militares también estaba prácticamente aniquilada. Hubo, sin embargo, quienes en esa coyuntura lo intentaron. Uno de esos casos fue el de Onofre Pinto, dirigente de la 
La negativa de asilo territorial a este grupo de brasileños perseguidos en "patria ajena" y las intimidaciones ejercidas desde la Secretaría de Gobernación para obligar a algunos de ellos a abandonar el país en la misma coyuntura en la que se aplicaba una política de puertas abiertas hacia los perseguidos políticos de origen chileno son comportamientos del gobierno mexicano en materia de asilo que no tienen precedente y son incompatibles con el prestigio y la tradición que México ha tenido como protector de perseguidos políticos.

El caso permite constatar un comportamiento de México en materia de asilo político mucho más complejo, en donde las respuestas a las peticiones de protección y el trato a los asilados han dependido de los perfiles políticos de los sujetos de asilo, de los contextos nacionales e internacionales e, incluso, de las instancias de gobierno en donde han sido procesadas. En este caso, por ejemplo, se hace evidente cómo en una misma coyuntura los asilados encuentran un tipo de respuesta en el servicio exterior, donde en atención a una vieja y prestigiosa tradición les abren las puertas de la embajada, y otro en la Secretaría de Gobernación, donde en función de criterios más políticos que humanitarios terminan por exigirles que abandonen el país.

\section{CONSIDERACIONES FINALES}

Documentamos en estas páginas dos casos de asilo político en México considerados excepcionales en relación con lo que se ha

\footnotetext{
Vanguardia Popular Revolucionaria (VPR) que en 1969 fue uno de los 15 presos políticos que había llegado a México en el intercambio por el embajador de Estados Unidos. En Cuba, a donde se dirigió después de México, había reclutado a varios exiliados para integrarse a la VPR y se trasladó después a Chile, donde vivió hasta que el golpe de Estado contra Salvador Allende lo llevó a exiliarse en Argentina. En julio de 1974 ingresó clandestinamente a Brasil donde fue asesinado. Su cuerpo nunca fue localizado y hasta hoy permanece como desaparecido político de la dictadura militar.
} 
entendido que fue el comportamiento "tradicional" del gobierno de México en materia de asilo político a lo largo del siglo xx y particularmente durante la segunda mitad frente a los exilios sudamericanos.

La excepcionalidad en ambos casos radica, por un lado, en la forma peculiar en la que se presentaron al gobierno de México las peticiones de asilo, y por otro, en el comportamiento que el gobierno de México tuvo con estos grupos de exiliados una vez que arribaron al país.

En ambos casos los grupos de asilados están integrados por personas, en su mayoría jóvenes, vinculadas a organizaciones de la izquierda armada que han sido desterrados por el régimen militar brasileño.

En el caso de los presos políticos rescatados y enviados a México en las operaciones de intercambio por funcionarios diplomáticos llevadas a cabo por organizaciones revolucionarias, el asilo otorgado por el gobierno de Díaz Ordaz fue concedido en una situación sin precedente: a petición del gobierno persecutor de los sujetos de asilo y de los gobiernos "amigos" cuyos representantes diplomáticos habían sido secuestrados en Brasil. Como el propio presidente aclaró, la concesión se hizo con el propósito de salvar la vida de los diplomáticos y de colaborar de manera eficiente con los militares brasileños en la resolución de un caso que significaba el golpe político más fuerte que habían recibido desde que tomaron por la fuerza el poder.

El caso pone en evidencia que el asilo político, una institución jurídica creada con el objetivo de proteger esencialmente la vida y la integridad de personas perseguidas en sus países por sus posiciones políticas, fue utilizado como un recurso diplomático para conceder favores a países amigos, y no exactamente para proteger a los que fueron asilados. Evidentemente, los presos políticos que fueron liberados se beneficiaron de manera indirecta con la decisión del gobierno mexicano, pero 
las condiciones de su estancia en México distaron de ser las de ciudadanos en libertad.

Precisamente, la peculiaridad en la forma en que el gobierno mexicano atendió este caso en su territorio radica en haber impuesto a los asilados un abierto esquema de control y vigilancia presentado como medida de protección que implicaba el reconocimiento de su "peligrosidad" advertida por los militares brasileños en función de intereses de seguridad nacional, lo que en el contexto de la guerra fría puede interpretarse como una medida de contención en el marco de una concepción hemisférica de seguridad ante la supuesta amenaza comunista que el gobierno de México compartía y que de hecho había utilizado para justificar la represión al movimiento estudiantil mexicano apenas unos meses atrás.

En el caso de los brasileños procedentes de Chile nos encontramos con una situación sui generis: la protección en la embajada mexicana de un conjunto de personas que son perseguidas en un país diferente al suyo, de hecho, en su país de asilo, y a quienes una vez estando en México se les niega el asilo territorial bajo el argumento de que no se puede conceder la prerrogativa a quienes son perseguidos en "patria ajena".

La protección a personas que enfrentan una doble persecución, en su país y en su país de asilo, no ha sido un fenómeno recurrente en las embajadas mexicanas -tampoco ha sido un fenómeno muy estudiado en la historiografía sobre los exilios políticos-; ésa es ya una primera peculiaridad del caso. Sin embargo, lo que consideramos mucho más excepcional es la negativa de asilo territorial por parte del gobierno mexicano a ese grupo de perseguidos políticos y la intimidación de la que fueron objeto algunos de ellos desde la Secretaría de Gobernación para obligarlos a abandonar el país.

Se trata de casos en los que el gobierno mexicano otorga una protección con límites y restricciones a grupos de perseguidos políticos que comparten características como las de ser en su 
mayoría jóvenes vinculados a organizaciones revolucionarias a los que el régimen militar brasileño ha impuesto la pena del destierro, pensada no sólo como un castigo que les impida regresar a su país, sino también como un estigma que los distinga y les afecte negativamente en el exilio, lo cual, como se muestra en este trabajo, tiene efecto en su experiencia de asilo en México.

Nos encontramos, pues, frente a dos casos en los que México muestra un comportamiento singular en materia de asilo político, inesperado en función de su tradición hospitalaria, lo que invita a entender de una manera más amplia y más compleja el papel que tuvo este país frente a las migraciones políticas durante la segunda mitad del siglo xx.

\section{SIGLAS Y REFERENCIAS}

AGN Archivo General de la Nación, Ciudad de México, México. AHI-MRE Arquivo Histório do Itamaraty do Ministerio das Relações Exteriores, Brasil.

AHSRE Archivo Histórico de la Secretaría de Relaciones Exteriores, Ciudad de México, México.

ANB Arquivo Nacional do Brasil, Río de Janeiro, Brasil.

CISA Centro de Informações de Segurança da Aeronáutica, Brasil. DFS Dirección Federal de Seguridad, México.

DIPS Departamento de Investigaciones Políticas y Sociales, México.

SNI Serviço Nacional de Informações, Brasil.

SRE Secretaría de Relaciones Exteriores, México.

Aarão Reis, Marcelo Ridenti y Rodrigo Patto Sá Motta (orgs.) O golpe e a ditadura militar. 40 años depois (1964-2004), Bauru, Edusc, 2004.

Aguayo, Sergio, El 68. Los estudiantes, el presidente y la CIA, México, Ediciones Proceso, 2018.

Aguayo, Sergio, La Charola. Una historia de los servicios de inteligencia en México, México, Ediciones Proceso, 2015.

AndúJar de Jesús, Eusebio, “Exiliados bolivianos en la unam”, en Archipiélago. Revista Cultural de Nuestra América, 23: 90 (2015), pp. 21-25. 
Arriola, Carlos, “El acercamiento mexicano-chileno", en Foro Internacional, XIv: 4 (56) (abr.-jun. 1974), pp. 507-547.

Bernetti, Jorge Luis y Mempo Giardinelli, México, el exilio que hemos vivido. Memoria del exilio argentino en México durante la dictadura: 19761983, Buenos Aires, Octubre, 2014.

Borges, Nilson, “A Doutrina de Segurança Nacional e os governos militares”, en Ferreira y Almeida (orgs.), 2012, pp. 15-42.

Buriano Castro, Ana, Silvia Dutrénit y Guadalupe Rodríguez de ITA, Tras la memoria. El asilo diplomático en tiempos de la Operación Cóndor, México, Gobierno del Distrito Federal, Instituto de Cultura de la Ciudad de México, Instituto de Investigaciones Dr. José María Luis Mora, 2000.

Buriano, Ana, "El exilio uruguayo en la ciudad de México", en Latinoamericanos en la Ciudad de México, México, Gobierno de la Ciudad de México, Instituto de Cultura de la Ciudad de México, 1999, pp. 19-28.

Centro de DOCUMENTACión, INFORMACIÓN Y ANÁLISIs, Informes presidenciales. Gustavo Díaz Ordaz, México, Cámara de Diputados, LX Legislatura, 2006.

Collado Herrera, María del Carmen, "La Guerra Fría, el movimiento estudiantil de 1968 y el gobierno de Gustavo Díaz Ordaz. La mirada de las agencias de seguridad de Estados Unidos”, en Secuencia, 98 (mayo-ago. 2017), pp. 158-203.

Da Cruz, Fabio Lucas, "Frente Brasileño de Informaciones e Campanha: os jornais de brasileiros exiliados no Chile e na França (1968-1979)", tesis de maestría, São Paulo, Universidade de São Paulo, 2010.

DA Cruz, Fabio Lucas, "Brasileiros no exílio. Argel como local estratégico para a militância política (1965-1979)", tesis de doctorado en historia social, São Paulo, Universidade de São Paulo, 2016.

DA-Rin, Silvio, Hércules 56. O sequestro do embaixador Americano em 1969, Río de Janeiro, Zahar, 2008.

De Andrade Porfirio, Pablo, "A trajetória de Francisco Julião no exiíio e as relações entre Brasil e México, 1965-1969”, en Revista Eletrônica da ANPHLAC, 18 (ene.-jun. 2015), pp. 87-120. 
Díaz Prieto, Gabriela, "Un exilio venturoso: chilenos en México (19731990)”, en Garciadiego y Kourí (eds.), 2010, pp. 793-815.

Díaz Silva, Elena, Aribert Reimann y Randal Sheppard (eds.), Horizontes del exilio. Nuevas aproximaciones a la experiencia de los exilios entre Europa y América Latina durante el siglo XX, Madrid, Iberoamericana Vervuert, 2018.

Ferreira, Jorge y Lucila de Almeida (orgs.), O tempo da ditadura: regime militar e movimentos sociais em fins do século $X X$, Río de Janeiro, Civilização Brasileira, 2012.

Garciadiego, Javier y Emilio Kourí (eds.), Revolución y exilio en la historia de México, México, El Colegio de México, Centro Katz de Estudios Mexicanos, The University of Chicago, 2010.

Green, James N., A pesar de vocês, Río de Janeiro, Companhia das Letras, 2009.

Hidalgo Castellanos, Diana Guadalupe, "Um olhar na vida de exilio de Francisco Julião”, tesis de maestría, São Paulo, Universidade de São Paulo, 2002.

LARSON, Judith, "La guerrilla en América Latina, ¿terrorismo o guerra popular?”, en Revista de Sociología (1977), pp. 91-112.

Meyer, Eugenia y Eva Salgado, Un refugio en la memoria, México, Universidad Nacional Autónoma de México, Oceano, 2002.

Meyer, Lorenzo, "La Guerra Fría en el mundo periférico: el caso del régimen autoritario mexicano. La utilidad del anticomunismo discreto", en SPENSER (coord.), 2004, pp. 95-117.

Morales Muñoz, Daniela, El exilio brasileño en México durante la dictadura militar, 1964-1979, México, Secretaría de Relaciones Exteriores, Red de Archivos Diplomáticos Iberoamericanos, 2018.

Norambuena, Carmen, Adriana Palomera y Ana López, "Brasileños en Chile durante la dictadura militar: Doble refugio 1973-1975", en História Unisinos, 22: 3 (sep.-oct. 2018), pp. 453-465.

Pereira, Anthony W., Ditadura e repressão. O autoritarismo e o Estado de Direto no Brasil, no Chile e na Argentina, São Paulo, Paz e Terra, 2005. 
Pinheiro Machado, Cristina, Os exiliados. 5 mil brasileiros a espera da anistía, Rio de Janeiro, Alfa Omega, 1979.

Pirker, Kristina y Omar Núñez Rodríguez, "La revolución salvadoreña necesita de la solidaridad del pueblo mexicano. Exilio salvadoreño y activismo político en la Ciudad de México", en Vázquez Olivera y Campos (coords.), 2016, pp. 285-308.

Prestes Massena, Andreia, "Entre Brasil e Moçambique: os caminhos percorridos no exílio", en Estudios Interdisciplinarios de América Latina y el Caribe, 20: 1 (2009), pp. 67-92.

RodRíGuez de ITA, Guadalupe, “Tres asilos otorgados por México a un mismo antitrujillista”, en Tzintzun. Revista de Estudios Históricos, 52 (jul.-dic. 2010), pp. 99-140.

Rodríguez de ITA, Guadalupe, "Un México protector de asilados y refugiados durante la Guerra Fría. Entre la definición y la ambigüedad", en Dimensión Antropológica, año 15, 43 (mayo-ago. 2008), pp. 121-158.

Rojas Mira, Claudia Fedora, "El exilio político chileno: La Casa de Chile en México (1973-1993), una experiencia singular", tesis de doctorado en Estudios Americanos con mención en historia, Santiago, Universidad de Santiago de Chile, 2013.

Rollemberg, Denise, Exílio. Entre raízes e radares, Río de Janeiro, Récord, 1999.

SÁenz Carrete, Erasmo, El exilio brasileño en Chile, Francia y México: la teoría de la dependencia", en II Jornadas de Trabajo sobre Exilios Políticos del Cono Sur en el siglo xx, noviembre 2014.

SALles, Vania, "Migrantes y trashumantes: percepciones sobre el exilio", en Latinoamericanos en la Ciudad de México, México, Gobierno de la Ciudad de México, Instituto de Cultura de la Ciudad de México, 1999, pp. 29-52.

Schneider Marques, Teresa Cristina, "Ditadura, exílio e oposição: os exiliados brasileiros no Uruguay (1964-1967)”, tesis de maestría, Cuiabá, Universidade Federal de Mato Grosso, 2006.

Schneider Marques, Teresa Cristina, "Marcha e os exiliados brasileiros no Uruguay: A oposição à ditadura militar a través da imprensa”, en Revista Territórios e Fronteiras, 2: 1 (ene.-jun. 2009), pp. 62-80. 
Schneider Marques, Teresa Cristina, "O exílio e as transformações de ação coletiva: A esquerda brasileira no Chile e na França (1968-1978)", en Dados. Revista de Ciências Sociais, 60: 1 (2017), pp. 239-269.

Secretaría de Relaciones Exteriores, Memoria de la Secretaría de Relaciones Exteriores del 1 de septiembre de 1969 al 31 de agosto de 1970, México, Talleres Gráficos de la Nación.

Spenser, Daniela (coord.), Espejos de la Guerra Fría: México, América Central y el Caribe, México, Centro de Investigaciones y Estudios Superiores en Antropología Social, Secretaría de Relaciones Exteriores, Miguel Ángel Porrúa, 2004.

Sznajder, Mario y Luis Roniger, La política del destierro y el exilio en América Latina, México, Fondo de Cultura Económica, 2013.

Tarrés, María Luisa, "Exilios en México. Miradas de una chilena", en Latinoamericanos en la Ciudad de México, México, Gobierno de la Ciudad de México, Instituto de Cultura de la Ciudad de México, 1999, pp. 53-62.

Tavares, Flávio, Memórias do esquecimento, São Paulo, Editora Globo, 1999.

Toussaint, Mónica, “¿Activismo o intervencionismo? México frente a Nicaragua, 1978-1982”, en VÁzquez Olivera y Campos (coords.), 2016, pp. 49-77.

Uchôa Cavalcanti, Pedro Celso e Jovelino Ramos (orgs.), Memórias do exílio. Brasil 1964-19?? De muitos caminos, São Paulo, Livramento, 1978, vol. 1, pp. 250-252.

Vázquez Olivera, Mario y Fabián Campos (coords.), México ante el conflicto centroamericano. Testimonio de una época, México, Bonilla Artigas Editores, Universidad Nacional Autónoma de México, 2016.

Velasco Villanueva, Marco Antonio, “'Brasil. Amelo o déjelo’: El caso del exilio de académicos brasileños en México y sus aportaciones”, II Jornadas de Trabajo sobre Exilios Políticos del Cono Sur en el siglo xx, 2014; Agendas, problemas y perspectivas conceptuales, Montevideo, Uruguay, 5, 6 y 7 de noviembre de 2014.

Viz Quadrat, Samantha, "Muito Além das fronteiras", en Aarão Reis, RiDenti y Patto Sá MotTa (orgs.), 2004, pp. 315-328. 
Yankelevich, Pablo, "Exilios: México en la memoria latinoamericana", en Díaz Silva, Reimann y Sheppard (eds.), 2018, pp. 19-48.

Yankelevich, Pablo, Ráfagas de un exilio. Argentinos en México, 1974-1983, México, El Colegio de México, 2009.

Yankelevich, Pablo, "La Comisión Argentina de Solidaridad. Notas para el estudio de un sector del exilio argentino en México", en Yankelevich (coord.), 2002, pp. 281-302.

Yankelevich, Pablo (coord.), México, país refugio. La experiencia de los exilios en el siglo XX, México, Instituto Nacional de Antropología e Historia, Plaza y Valdés, 2002.

Yankelevich, Pablo (coord.), En México entre exilios. Una experiencia de sudamericanos, México, Secretaría de Relaciones Exteriores, Instituto Tecnológico Autónomo de México, Plaza y Valdés, 1998.

Otras referencias

Conversación con Flávio Tavares, Porto Alegre, Brasil, 30 de noviembre de 2013.

Conversación con Reinaldo Guarany, Río de Janeiro, Brasil, 4 de abril de 2015.

Conversación con Wilson Barbosa do Nascimento, São Paulo, Brasil, 10 de diciembre de 2015. 
